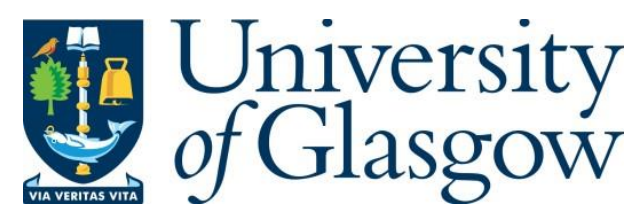

You, S., Tong, H., Armin-Hoiland, J., Tong, Y. W. and Wang, C.-H. (2017) Technoeconomic and greenhouse gas savings assessment of decentralized biomass gasification for electrifying the rural areas of Indonesia. Applied Energy, 208, pp. 495-510.

There may be differences between this version and the published version. You are advised to consult the publisher's version if you wish to cite from it.

http://eprints.gla.ac.uk/153185/

Deposited on: 6 June 2018

Enlighten - Research publications by members of the University of Glasgow http://eprints.gla.ac.uk 


\title{
Techno-economic and Greenhouse Gas Savings Assessment of Decentralized Biomass Gasification for Electrifying the Rural Areas of Indonesia
}

\author{
Siming You ${ }^{\mathrm{a}}$, Huanhuan Tong ${ }^{\mathrm{a}}$, Joel Armin-Hoiland ${ }^{\mathrm{b}}$, Yen Wah Tong ${ }^{\mathrm{a}, \mathrm{c}}$, Chi-Hwa Wang ${ }^{\mathrm{c}^{*}}$ \\ ${ }^{a}$ NUS Environmental Research Institute, National University of Singapore, 1 Create Way, Create \\ Tower, \#15-02, Singapore 138602 \\ ${ }^{\mathrm{b}}$ All Power Labs, 1010 Murray Street, Berkeley, California, CA 94710 \\ ${ }^{c}$ Department of Chemical and Biomolecular Engineering, National University of Singapore, 4 \\ Engineering Drive 4, Singapore 117585 \\ Submitted to Applied Energy
}

September 2017

*Corresponding Author. Tel: +65 65165079; Fax: +65 67791936;

Email: chewch@nus.edu.sg (C. H. Wang) 


\begin{abstract}
This study explored the feasibility of decentralized gasification of oil palm biomass in Indonesia to relieve its over-dependence on fossil fuel-based power generation and facilitate the electrification of its rural areas. The techno-feasibility of the gasification of oil palm biomass was first evaluated by reviewing existing literature. Subsequently, two scenarios (V1 and V2, and M1 and M2) were proposed regarding the use cases of the village and mill, respectively. The capacity of the gasification systems in the V1 and M1 scenarios are determined by the total amount of oil palm biomass available in the village and mill, respectively. The capacity of the gasification systems in the V2 and M2 scenarios is determined by the respective electricity demand of the village and mill. The global warming impact and economic feasibility (net present value (NPV) and levelized cost of electricity (LCOE)) of the proposed systems were compared with that of the current practices (diesel generator for the village use case and biomass boiler combustion for the mill use case) using life cycle assessment (LCA) and cost-benefit analysis (CBA). Under the current daily demand per household $(0.4 \mathrm{kWh})$, deploying the V2 system in $10^{4}$ villages with 500 households each could save up to 17.9 thousand tons of $\mathrm{CO}_{2 \text {-eq }}$ per year compared to the current diesel-based practice. If the electricity could be fed into the national grid, the M1 system with $100 \%$ capacity factor could provide yearly GHG emissions mitigation of $5.8 \times 10^{4}$ ton $\mathrm{CO}_{2 \text {-eq }}$, relative to the current boiler combustion-based reference scenario. M1 had a positive mean NPV if the electricity could be fed into the national grid, while M2 had a positive mean NPV at the biochar price of $500 \mathrm{USD} /$ ton. Under the current electricity tariff (ET) $(0.11 \mathrm{kWh})$ and the biochar price of $2650 \mathrm{USD} / \mathrm{ton}$, daily household demands of 2 and $1.8 \mathrm{kWh}$ were required to reach the break-even point of the mean NPV for the V2 system for the cases of
\end{abstract}


300 and 500 households, respectively. The average LCOE of V2 is approximately one-fourth that of the reference scenario, while the average LCOE of V1 is larger than that of the reference scenario. The average LCOE of M1 decreased to around $0.06 \mathrm{USD} / \mathrm{kWh}$ for the case of a $100 \%$ capacity factor. Sensitivity analysis showed that the capital cost of gasification system and its overall electrical efficiency had the most significant effects on the NPV. Finally, practical system deployment was discussed, with consideration of policy formulation and fiscal incentives.

Keywords: Biomass gasification; Biochar; life cycle assessment; cost-benefit analysis; decentralization.

\section{INTRODUCTION}

Bioenergy technologies have a great potential to help resolve urgent global challenges, such as lack of effective waste management and disposal, climate change, and energy and resource depletion. Extensive development of bioenergy systems has occurred in recent years, and a wide variety of systems have been proposed, with the aim of sustainably processing various biomass types and benefitting users of different social-environmental backgrounds.

For example, willow chips were converted into bioethanol via enzyme-catalyzed hydrolysis and fermentation, and electricity was generated using a biomass-fired integrated gasification combined cycle technology, both of which had more favorable environmental and energy performance than conventional fossil fuel-based energy sources (González-García et al., 2012). Crop residue-based gasification systems feature significant climate change mitigation benefits and short climate impact mitigation periods (Field et al., 2016; Yang \& Chen, 2014). Rice straw was converted into syngas (also known as producer gas) via gasification for the synthesis of 
dimethyl ether, which can be used as automotive fuel for diesel engines and a liquefied petroleum gas supplement for household applications (Silalertruksa et al., 2013). Mazzola et al. (2016) showed that utilizing woody biomass-based gasification could effectively reduce the levelized cost of electricity (LCOE) of isolated microgrids by 38\%, relative to diesel enginebased systems. The greenhouse gas (GHG) emissions of cornstalk biomass briquette fuel was shown to be a full order of magnitude lower than that of coal in China (Wang et al., 2017).

Indonesia is the largest energy consumer in Southeast Asia (SEA), accounting for $36 \%$ of the region's energy consumption (Azam et al., 2015). Currently, over 90\% of electricity produced in Indonesia comes from fossil fuels, with coal accounting for over 50\% (ADB, 2015), making Indonesia one of the largest greenhouse gas (GHG) emitters in the world. The Indonesian government plans to reduce the country's dependence on fossil fuels by increasing the share of renewable energy sources in the primary energy mix, which would contribute to reduce its GHG emission by $26 \%$ below the the business-as-usual (BAU) value (ADB, 2015; Paltseva et al., 2016).

Apart from its environmental concerns related to electricity generation, Indonesia has also experienced great difficulty in expanding its current national grid and related energy services to remote rural areas, largely due to its archipelago geography and forested countryside. Low population density and electricity demand, along with low paying capacity of rural residents, make the long-distance transmission of centralized electricity prohibitively expensive (Pode et al., 2015). As a result, there were still over 10 million households without access to electricity in 2016 (ADB, 2016a). Decentralized power generation therefore represents perhaps the best solution to the country's rural electrification dilemma. This decentralization could be 
accomplishe by transmitting electricity from distributed energy resources to surrounding households via "mini-grids". Such decentralized systems are particularly suitable in the use cases of remote, mountainous villages where electricity access is a central economic and social issue (Kaundinya et al., 2009). However, for the electrification of rural areas, power generation systems based on the fossil fuels are generally less economically feasible than those based on renewable energy resources (Chakrabarti \& Chakrabarti, 2002). Overall, decentralized renewable energy systems should therefore be proposed for electrifying rural areas.

Indonesia has the highest biomass energy potential in the SEA region, with oil palm biomass being the dominant biomass source (Ahmed et al., 2017). The country produces more palm oil than any other nation, accounting for 52\% of global production in $2012-2013(\mathrm{Ng} \& \mathrm{Ng}, 2013)$. Gravimetrically, only $10 \%$ of a palm tree will be converted to oil products, while the rest of a tree becomes waste biomass (Yang et al., 2006). Solid oil palm biomass waste includes oil palm fronds and trunk (OPF and OPT), produced from pruning and felling during field plantation operations, as well as empty fruit bunches (EFB), palm kernel shells (PKS), and palm mesocarp fibers (PMF), generated as a byproduct of the palm oil production process in mills. This oil palm biomass has not been fully utilized for power generation, and the current biomass waste combustion-based method of power generation causes problems typical to biomass combustion, such as considerable air pollutant emissions and limited energy efficiency. Biomass gasification is an environmentally friendly alternative for power generation from oil palm biomass. Prior studies (e.g., Ariffin et al. (2016a); Ariffin et al. (2016b); Atnaw et al. (2014a); Guangul et al. (2013); Guangul et al. (2012); Ogi et al. (2013)) have shown that oil palm biomass has a great potential as feedstock for gasification for energy production. Moreover, gasification is suitable 
for small-scale decentralized applications, which conforms well with the relatively small electricity demand for rural households (Blum et al., 2013; Vijaya et al., 2008). Finally, biochar, a fixed carbon byproduct of the gasification process, can be used as a soil amendment to facilitate carbon sequestration and climate change mitigation (Lehmann et al., 2006).

Environmental and economic evaluation must be conducted prior to the deployment of energy systems in order to consider the needs of various stakeholders, including policymakers, private investors, and end users. First, policymakers are interested in the environmental benefits (e.g. GHG mitigation) of the system relative to existing processes, which can be estimated through life cycle analysis (LCA). Second, investors desire profitability, as their investment interests are dependent on the commercial viability of the system, as evaluated using cost-benefit analysis (CBA). Indeed, one of the major barriers to the success of existing decentralized bioenergy systems has been their commercial infeasibility (Mangoyana \& Smith, 2011). Third, the electricity should be affordable to the end users, which is critical for the long-term viability of the project (Palit et al., 2011). However, most of the existing studies evaluated the feasibility of decentralized bioenergy systems using only environmental or only economic criteria. There has yet to be a comprehensive study evaluating both the techno-economic feasibility and the environmental sustainability of bioenergy systems that are designed to address needs of all relevant stakeholders.

In this work, we study the potential of decentralized gasification systems in the disposal of oil palm biomass and the electrification of rural areas in Indonesia in terms of both their technoeconomic feasibility and environmental sustainability. The techno-feasibility of the gasification technology is firstly reviewed based on existing studies. Then, two gasification-based system 
designs are proposed with respect to villages and mills and are compared with existing practices from environmental and economic perspectives using LCA and CBA, respectively. The conditions supporting commercial viability of gasification-based systems are identified. The practical deployment of the systems is also discussed.

\section{METHODOLOGY}

\subsection{System and Scenario Design}

This work considers a representative palm oil mill that is supported by 9000 ha (on average) of plantations, distributed throughout the surrounding villages (Yuliansyah \& Hirajima, 2009). The average population of a village was 1217 (Gatto et al., 2017), while the average size of a household was 4.3 people (Lee et al., 2014), which suggests an average of $c a 300$ households per village. To consider the variation of household number, 300 and 500 households per village are considered and the whole village shares a single gasification system. According to the "PIR Trans" smallholder oil palm farming program, each household owns a 2-ha plot (Paoli et al., 2014; Pauli et al., 2014). The production of oil palm biomass in Indonesia is summarized in Table 1. Sung (2016) estimated that up to $0.9-1.5$ ton $\mathrm{ha}^{-1} \mathrm{yr}^{-1}$ OPF and OPT could be removed from a mature oil palm plantation to maintain an acceptable soil nutrient condition without adding extra fertilizers. We consider that an amount equivalent to that of OPT is available for power production from the field.

A schematic diagram of the reference and proposed scenarios are shown in Figure 1. Reflecting current practice in the study area, in the reference scenario (Figure 1 (a)), the villages were powered by diesel generators, while the mill was powered by boiler combustion of oil palm 
biomass. In the village reference scenario (D), each household has a $2 \mathrm{~kW}$ diesel generator that is operated for $6 \mathrm{~h}$ per day for 365 days per year. In the mill reference scenario, two sub-scenarios (R1 and R2) are considered: the capacity of R1 is determined by the amount of biomass available, while the capacity of $\mathrm{R} 2$ is determined by the daily electricity demand of the mill. The systems of R1 and R2 are operated for $12 \mathrm{~h}$ per day for 264 days per year.

The proposed village and mill scenarios (Figure 1 (b)) have two sub-scenarios, respectively. In the first village sub-scenario (V1), the capacity of the system is designated by the amount of OPT available, while the actual electricity generation is reflected by the capacity factor, which is defined as the ratio between the energy output and the capacity of the system. A $100 \%$ capacity factor means that the system consumes all the biomass available. The system in the V1 scenario has the ability to cater to future increase in electricity demand. In the following analysis, we will consider a special case in which the system has a $100 \%$ capacity factor to fully utilize the biomass available for biochar production, but electricity is used only to satisfy the daily village electricity demand (the aggregate of household electricity demand in the village). In the second village sub-scenario (V2), the capacity of the system is designated by the daily village electricity demand. Hence, the system in the V2 scenario always has a capacity factor of $100 \%$. All of the village scenarios are without connection to the national grid and operate for $6 \mathrm{~h}$ per day for 365 days per year. Since energy storage systems (e.g. batteries) are relatively capital intensive (Ho et al., 2015), they are not included in the system design.

The first mill sub-scenario (M1) has a capacity designated by the amount of biomass available (i.e. EFB, PKS, and PMF). Without the national grid, the capacity factor of the system is dependent upon the electricity demand of the mill. However, if the national grid is available, 
which is true for some mills located in relatively large towns, the system could have a capacity factor of $100 \%$ with the electricity being fed into the grid. In the following analysis, we will consider a special case in which the system has a $100 \%$ capacity factor to fully utilize the biomass available for biochar production, but only electricity is only used to satisfy the daily mill demand. The second sub-scenario (M2) has a capacity designated by the electricity demand of the mill. The mill scenarios are operated for $12 \mathrm{~h}$ per day for 264 days per year. The differences between the considered scenarios are listed in Table 2.

\subsection{Gasification and Biomass}

There are three major types of gasifiers: fixed bed, fluidized bed, and entrained flow. Fixed bed gasifiers are further divided into downdraft and updraft architectures. Guangul et al. (2012) compared the different types of gasifiers for processing OPF and found that fixed bed downdraft gasifiers were the best choice for use with OPF feedstock, based on seven criteria, including fabrication cost, ease of operation, tar content, and cold gas efficiency. Downdraft gasifiers also have the advantage of being suitable for the small-scale decentralized power generation (Martínez et al., 2012). Hence, downdraft gasifiers are the type considered in this work.

A typical downdraft fixed bed gasification system is illustrated in Figure 2. The feedstock is introduced into the hopper and pretreated in the drying bucket by the heat from the hot producer gas. The motorized screw feeder moves the feedstock to the heat exchanger, where the drying and pyrolysis processes of gasification take place. The combustion and reduction processes take place at the bottom of the reactor. The vacuum from the engine pulls the gas through the system into the engine, lowering the pressure in the reactor below atmospheric pressure and drawing the 
ambient air into the combustion zone of the reactor. The producer gas from the reactor is first cleaned with a cyclonic separator to remove particulate matter and then goes around the drying bucket to heat up the feedstock. The producer gas then goes through a filter (to remove tar), after which it goes into the gas engine for power generation. To initiate the gasification process, a few $\mathrm{mL}$ of auxiliary fuel (kerosene) is used to ignite the reactor bed through an ignition port on the side wall of the reactor. The biochar is obtained at the bottom of the reactor. The power output is calculated as Moghadam et al. (2014)

$$
P=F R \times L H V_{\text {feedstock }} \times C G E \times E F
$$

where FR is the feeding rate $(\mathrm{kg} / \mathrm{h})$ and $\mathrm{EF}$ is the electrical efficiency of the gas engine. LHV is the lower heating value and estimated based on the higher heating value (HHV), as shown in the following Table 3 under an assumption of $10 \mathrm{wt} . \%$ moisture content with the empirical equation (Channiwala \& Parikh, 2002): LHV=HHV-0.212 $\mathrm{M}_{\mathrm{H}^{-}}-0.0245 \mathrm{M}_{\mathrm{m}}-0.008 \mathrm{M}_{\mathrm{O}} \cdot \mathrm{M}_{\mathrm{H}}, \mathrm{M}_{\mathrm{m}}$, and $\mathrm{M}_{\mathrm{O}}$ are the weight percentage of hydrogen, moisture, and oxygen, respectively. Based on Table 3, the average value of cold gas efficiency (CGE), 58\%, is used. EF is set at $42 \%$ for a typical gas engine (François et al., 2013). Hence, the overall electrical efficiency is around 24\%, which is consistent with values reported by previous studies (Arena et al., 2010; Aziz et al., 2017). Electricity is also consumed by the gasification system itself because of the use of motors, the automated controls, and the electricity loss in the system. This onboard consumption is termed auxiliary electricity consumption (AEC). AEC is considered to be $10 \%$ of the total electricity generation (Palit et al., 2011).

Raw OPF and OPT have a moisture content of approximately 70 wt.\% (Bocci et al., 2014; González et al., 2015), while EFB, PKS, and PMF have a moisture content of 65 wt.\%, 10 wt.\%, 
and $40 \mathrm{wt} . \%$, respectively (Paltseva et al., 2016). The acceptable feedstock moisture content for gasifiers is generally suggested to be lower than $25 \mathrm{wt} . \%$, because high moisture content can adversely affect gas yields, carbon conversion efficiency, and overall gasification efficiency (Jarungthammachote \& Dutta, 2008; Vijaya et al., 2008). OPF, OPT, EFB, and PMF must undergo a drying pretreatment process prior to gasification. The moisture content of OPF could be effectively reduced to 16 wt.\% after 20-day air drying (Guangul et al., 2012). Air drying is adopted as an economical and feasible method, in view of the abundant solar energy and space in the rural areas of Indonesia.

The chemical and energy properties of oil palm biomass are shown in Table 3. OPF, PKS, and EFB could have high volatile contents, up to $80 \mathrm{wt} . \%$ on a dry basis. The high volatile content suggests that it has a high reactivity (rapid volatilization) during the gasification process. The resulting producer gas may contain high tar concentrations, which could be mitigated in a downdraft gasifier (Atnaw et al., 2013). One method is filtration, which can remove tar from the the gas stream prior to its utilization in a genset for power generation. The ash content of oil palm biomass is generally less than $10 \mathrm{wt} . \%$ on a dry basis (Ariffin et al., 2016b; Guangul et al., 2013; Guangul et al., 2012; Lahijani \& Zainal, 2014; Moghadam et al., 2014), which is favorable for mitigating some ash-related problems, such as slagging and clinkering. The carbon and energy contents of the oil palm biomass are comparable to those of some other commonly-used biomass gasification feedstock, such as corn stalk and wheat straw, suggesting that oil palm biomass waste is an energy efficient source for power generation from gasification.

Table 4 lists the existing gasification experiments on oil palm biomass with fixed bed downdraft gasifiers. The LHV of producer gas ranges from 3.75 to $5.9 \mathrm{MJ} / \mathrm{Nm}^{3}$, which is 
comparable to that of syngas from other types of biomass such as coconut shells, hazelnut shells, and woody biomass (Atnaw et al., 2014b). The carbon conversion efficiency and CGE are larger than $70 \%$ and $50 \%$, respectively. A higher CGE suggests a greater power generation potential from the biomass. The biochar yield ranges from $5.2 \%$ to $29.13 \%$ and the carbon content of biochar from the gasification of $\mathrm{OPF}, \mathrm{PKS}$, and $\mathrm{EFB}$ is $91 \%, 81 \%$, and $75 \%$, respectively (Mahmood et al., 2015). When biochar produced by gasification systems is used as soil amendment, it serves as a carbon sink and facilitates carbon abatement (Lehmann et al., 2006). Gasification biochar can also improve soil structure, nutrient and water retention, and increase crop productivity (Carter et al., 2013; Hansen et al., 2015). However, studies of the effects of the gasification biochar specifically from oil palm biomass is still lacking.

\subsection{LCA}

A LCA was conducted to identify the most environmental-friendly power generation strategies for the village and mill use cases. The LCA boundary (gate-to-gate) is illustrated in Figure 3. Inventory data was collected regarding the stages of infrastructure construction, oil palm biomass transportation, thermal conversion (gasification or combustion), exhaust gas purification, ash management, and avoided emissions by the generated products upon substituting existing materials and energy carriers. The key parameters in life cycle inventory (LCI) are shown in Table 5, and detailed explanations about infrastructure construction are given in Table S1 (Please see the Supplementary Material). The GHG emissions from palm plantations are outside of the LCA boundary in this study. It is commonly agreed that the global warming (GW) contribution of the upstream operation (mainly plantation) to the farm gate is predominant 
for a cradle-to-gate boundary (Sastre et al., 2014). The impacts of palm plantation, especially the transformation of tropical rain forests to plantation, is so large that the effects of other factors on oil palm biomass could hardly be observed (Jungbluth et al., 2007; Wiloso et al., 2015). Given that the choice of treatment strategy on oil palm biomass has a limited relevance on the practice of plantation, removing palm plantation from the considered scenarios in the gate-to-gate boundary does not adversely affect the comparison of results and even allows a "zoom-in" differentiation of the various utilization options of oil palm biomass.

The $\mathrm{CO}_{2 \text {-eq }}$ emissions during the thermal conversion of oil palm biomass are assumed to be carbon-neutral and not to contribute to the $\mathrm{GW}$ impact, since the amount of $\mathrm{CO}_{2 \text {-eq }}$ released during biomass utilization is offset by the $\mathrm{CO}_{2 \text {-eq }}$ eliminated from the atmosphere by photosynthesis during the growth of the biomass from which the emissions are released (Eksi \& Karaosmanoglu, 2017). The gasification systems in the villages are assumed to occupy the shrubland in the vicinity of the villages, while forest cleared to accommodate the gasification (or boiler combustion) system of the mill. Shrubland soil and tropical forest soil were reported to have a soil organic carbon (SOC) content of 54 ton C/ha (i Canals et al., 2007) and 62 ton C/ha (Guillaume et al., 2015), respectively, which is lost during the land transformation. One $\mathrm{kg} \mathrm{C}$ released to the atmosphere from the $\mathrm{SOC}$ deficit is equivalent to $3.67 \mathrm{~kg} \mathrm{CO}_{2-\mathrm{eq}} \mathrm{GHG}$ emissions, and the resulted GW impact is allocated to the electricity produced from the land during the whole lifetime of the power system (25 years).

The functional unit for the village scenarios is set as the generation of $1 \mathrm{kWh}$ electricity. In the diesel generator reference scenario of the village (D), the OPT from pruning and replanting is left in the field as fertilizer, while the electricity in the households is provided by a diesel 
generator. Inventory of the generator manufacture and pollutant emissions during diesel burning are sourced from Ecoinvent data. In the proposed scenarios, chemical fertilizer is added to the field to make up the nutrient loss caused by the removal of OPT. Based on the element composition, the fertilizing value of 1 ton OPT is equal to $3.8 \mathrm{~kg} \mathrm{~N}, 1.1 \mathrm{~kg} \mathrm{P}_{2} \mathrm{O}_{5}, 3.1 \mathrm{~kg} \mathrm{~K}_{2} \mathrm{O}$ fertilizer on a dry basis, corresponding to $37.3 \mathrm{~kg} \mathrm{CO}_{2 \text {-eq }}$ if transportation is also taken into account. For the syngas and biochar yields, and CGE, the average values calculated based on Table 4 are used. The GHG emission from the engine running on syngas is calculated based on the measurement of Ahrenfeldt et al. (2005). The fly ash collected from the syngas cleaning process is considered to be disposed of in a landfill. The carbon in the biochar is classified as recalcitrant, with a sequestration rate of $80 \%$ of the total carbon contained in the biochar $(-2.35$ $\mathrm{kg} \mathrm{CO}_{2 \text {-eq }} / \mathrm{kg}$ biochar) (Galinato et al., 2011).

The functional unit for the mill scenarios is set as the treatment of all the oil palm biomass available in the mill (EFB, PKS, and PMF). In the reference scenario of mill (R2), all the biomass residues are sun-dried before combustion, and the bottom ash is utilized as $\mathrm{K}$ fertilizer (Maschowski et al., 2016). The inventory data about fly ash disposal, wastewater treatment and gaseous pollutant emissions during combustion is based on the Ecoinvent database. The generators are correspondingly dimensioned to produce sufficient electricity to power the palm oil milling process. In scenario R1, the national grid is available to the mill. Upon satisfying the electricity demand of the mill, extra electricity could be used to displace Indonesian grid electricity, which is based on $50 \%$ lignite coal, $29 \%$ petroleum products, $17 \%$ natural gas, $8 \%$ hydropower and 6\% renewables (Itten et al., 2012). Based on this power generation mix, $1048 \mathrm{~g}$ of $\mathrm{CO}_{2 \text {-eq }} \mathrm{GHG}$ emissions could be avoided by feeding $1 \mathrm{kWh}$ of electricity from the gasification 
system at the mill into grid. In M2 scenario, the capacity of the gasification system matches the current mill power consumption, and the remaining un-gasified portion of the biomass waste is processed through combustion to yield ash fertilizer, without energy recovery. The detailed life cycle inventory (LCI) is shown in Table 5 (more explanations on LCI are given in Table S1). We use GaBi LCA software and ReCiPe 1.08 Midpoint impact categories for the analysis.

\subsection{CBA}

A list of the cost and benefit information is given in Table 6. The cost of gasification and combustion systems is given for 2006 and 2007, respectively. The Chemical Engineering Plant Cost Index (CEPCI) is used to update these costs to the current year:

$$
\operatorname{Cost}_{i}=\operatorname{Cost}_{j}\left(C E P C I_{i} / C E P C I_{j}\right)
$$

where $i$ and $j$ denote the most recent year (2016) and base year (2007 and 2006, respectively). The annual values of CEPCI for 2006, 2007 and 2016 are 499.6, 525.4 and 541.7, respectively. The scale dependence of facility cost is considered by Jenkins (1997)

$$
\operatorname{Cost}_{k}=\operatorname{Cost}_{i}\left(S_{k} / S_{i}\right)^{f}
$$

where $S_{k}$ and $S_{i}$ denote the designed facility capacity and base facility capacity ( $9 \mathrm{~kW}$ (Abe et al., 2007) and 1 MW (Suramaythangkoor \& Gheewala, 2010) for small-scale (village) and medium-scale (mill) gasification systems; and 10 MW (Malek et al., 2017) for combustion systems, respectively). $f$ is the scaling factor and is set to be 0.7 (Sultana et al., 2010).

The benefits in the the gasification-based scenarios derive from sales of electricity and biochar. The national electricity tariff (ET) was around $\$ 0.11 / \mathrm{kWh}$ (current ET) in July 2016 (ADB, 2016b) which is similar to Indonesia's feed-in-tariff (FiT) rate for biomass-generated 
renewable energy (MEMR, 2017). To explore the effect of ET on the economics of the various scenarios, a range of $0.1-0.3 \mathrm{USD} / \mathrm{kWh}$ is considered in the analysis. On average, a remote rural household has an average daily electricity consumption of around $0.4 \mathrm{kWh}$ (current household demand) considering a major electricity consumption period between $18 \mathrm{pm}-24$ am (6 hours) (Blum et al., 2013). To explore the effect of household electricity demand, a range of 0.4 - 6 $\mathrm{kWh}$ is considered, which corresponds to a gasification capacity range of $22.2-333 \mathrm{~kW}$ and 37 $555 \mathrm{~kW}$ for the cases of 300 and 500 households, respectively, in V2. In V1, the full load capacities of the system are calculated to be 0.8 and $1.4 \mathrm{MW}$ for the cases of 300 and 500 households, respectively. In addition, the current household demand of $0.4 \mathrm{kWh}$ corresponds to a capacity factor of $2.8 \%$ for the system in V1. To study the effect of household electricity demand for sub-scenario V1, the capacity factor is varied from $2 \%$ to $40 \%$. The mill has a power consumption rate of $16 \mathrm{kWh}$ per ton of fresh fruit bunches (FFB) processed (Yusoff, 2006). A FFB production rate of 20.78 ton/ha/yr (backward calculated based on the EFB production rate) and a total number of 9000 ha plantations leads to an electricity demand of $c a 11000 \mathrm{kWh}$, based on 12 hours of operation per day. For sub-scenario M2, the daily electricity demand is varied from 10000 to $20000 \mathrm{kWh}$ to study the effect of electricity demand. For sub-scenario M1, the current electricity demand of $11000 \mathrm{kWh}$ per day means a capacity factor of $7.4 \%$. The capacity factor is varied from 5\% - 100\% to study its effect on electricity demand. The global average biochar price was reported to be $2650 \mathrm{USD} /$ ton (Ahmed et al., 2016). However, the biochar market is still not mature in Indonesia, despite consistent growth. The benefit of biochar is considered by setting the biochar price at 0,500 , and $2650 \mathrm{USD} / \mathrm{ton}$.

NPV and LCOE are used as the indicators in the CBA. NPV is calculated as 


$$
N P V=\sum_{t}^{L T} \frac{C_{i t}}{(1+r)^{t}}-C_{0}
$$

where $C_{i t}$ is the net cash inflow in a year $t ; C_{0}$ is the total initial investment; $L T=25$ years denotes the lifetime of facilities; $r$ is the discount rate and is set as 10\% (Ertürk, 2012; Manioğlu \& Y1lmaz, 2006). The LCOE represents the minimum electricity tariff for the break-even point of the project over its lifetime. It is calculated as

$$
L C O E=\sum_{t}^{L T} \frac{C_{c t}}{(1+r)^{t}} / \sum_{t}^{L T} \frac{E_{t}}{(1+r)^{t}}
$$

where $C_{c t}$ and $E_{t}$ is the overall cost and energy generation in a year $t$. To account for the uncertainty in the data regarding cost and benefit, the cost and benefit parameters in Table 6 are assumed to follow triangular distributions widely employed in CBA (Barrett et al., 2012; Withers et al., 2014). The values in Table 6 serves as the modes, while $150 \%$ and $50 \%$ of the nominal values are the upper and lower limits of triangular distributions. Monte Carlo simulation is used to model the triangular distributions in the analysis.

\section{RESULTS AND DISCUSSION}

\subsection{LCA}

\subsubsection{Village}

The net GW impact of the reference scenarios and proposed alternatives, as well as the contribution of each factor of the scenarios, per $\mathrm{kWh}$ of electricity generated, are shown in Figure 4. The process emissions, the manufacturing of diesel generator, and the use of diesel accounts for $60.8 \%, 28.5 \%$, and $10.7 \%$ of the net $\mathrm{GW}$ burden $\left(1261.6 \mathrm{~g} \mathrm{CO}_{2 \text {-eq }} / \mathrm{kWh}\right)$ of $\mathrm{D}_{1}$ (the reference scenario under the current daily household electricity demand of $0.4 \mathrm{kWh}$ ), 
respectively. In contrast, the proposed gasification-based scenarios $\left(\mathrm{V} 2_{1 / 300}\right.$ and $\left.\mathrm{V} 2_{1 / 500}\right)$ have a net $\mathrm{CO}_{2 \text {-eq }}$ reduction, due to the strong carbon sequestration effects of using biochar as a soil amendment. The GW benefit of biochar is $-272.4 \mathrm{~g} \mathrm{CO}_{2-\mathrm{eq}} / \mathrm{kWh}$, which has the potential to fully offset the GHG emissions associated with gasification-based electricity production. Generally, the dominant GW contributor to the gasification-based scenarios is the manufacturing of the gasification system, followed by fertilizer compensation (i.e. the extra fertilizer application due to removal of OPT from fields) and mini-grid construction. The GW burdens from the gasification process emissions, kerosene use, and land usage are in the range of $10^{-2}-10 \mathrm{CO}_{2}$ eq $/ \mathrm{kWh}$, which are orders of magnitude smaller than the major emissions contributors, and are thus negligible.

However, the scenarios $\mathrm{V} 1_{1 / 300}$ and $\mathrm{V} 1_{1 / 500}$ had a net $\mathrm{GW}$ burden, as the manufacturing of gasification system (i.e. the energy and raw materials during the manufacturing of gasification system) contributes $640.3 \mathrm{~g} \mathrm{CO}_{2 \text {-eq }} / \mathrm{kWh}$, which overtakes the $\mathrm{GW}$ benefit of biochar. Only when the gasification capacity is fully utilized and all of the available OPT waste is converted to energy and biochar, does the GW impact of the gasification system become net carbon negative, as shown in V1F scenarios. Although extra removal of field OPT increases the chemical fertilizer input, with a GW impact being sixty times higher than that in V1, significant saving from biochar could offset all the GW burdens, leading to a great environmental benefit around $7700 \mathrm{CO}_{2-\text { eq }} / \mathrm{kWh}$.

The comparison between the two cases with different numbers of households (300 vs. 500) revealed that increasing the number of households only slightly decreases the net GW impact, mainly because the environmental impact is dominated by system construction and carbon 
sequestration of biochar, which are assumed to have a linear relationship with the quantity of feedstock and are not affected by the capacity of the system. Among all the scenarios, ${\mathrm{V} 1 \mathrm{~F}_{1 / 500}}$ (V1 with all OPT removal to meet 500 household power demanding of $0.4 \mathrm{kWh}$ ) has the best

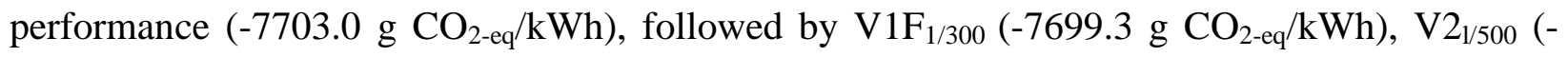
$\left.208.5 \mathrm{~g} \mathrm{CO}_{2 \text {-eq }} / \mathrm{kWh}\right), \mathrm{V}_{1 / 300}\left(-204.5 \mathrm{~g} \mathrm{CO}_{2 \text {-eq }} / \mathrm{kWh}\right), \mathrm{V}_{1 / 500}\left(428.0 \mathrm{~g} \mathrm{CO}_{2 \text {-eq }} / \mathrm{kWh}\right)$, and $\mathrm{V}_{1 / 300}$

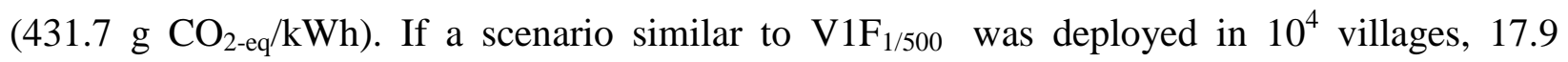
thousand fewer tons of $\mathrm{CO}_{2 \text {-eq }}$ could be emitted into the atmosphere per year compared to the current diesel-based practice.

\subsubsection{Mill}

The GW impacts of the reference scenarios and proposed alternatives for a mill is shown in Figure 5. Figure 5 shows that a net environmental saving is achieved in all the scenarios except for R2. For R2, M1 $\mathrm{N}_{1}$ and $\mathrm{M} 22_{1}$, the electricity is just satisfying the mill demand and not fed into the national grid, and thus the electricity displacement of GHGs is considered to be zero. The combustion process emissions (559.4 ton $\mathrm{CO}_{2 \text {-eq }} /$ year) accounts for $c a 77.9 \%$ of the $\mathrm{GW}$ burden for R2. The dominant process emissions contribution is attributed to $\mathrm{N}_{2} \mathrm{O}$ emissions, which is mainly formed by the reaction between $\mathrm{N}_{2}$ and $\mathrm{O}_{2}$ at elevated temperatures both in the boiler and engine. In addition, $20.1 \%$ of the total GHG emissions derives from the system construction (144.3 ton $\mathrm{CO}_{2 \text {-eq }} /$ year), while $2.0 \%$ is ascribed to the transportation of combustion bottom ash back to the fields as fertilizer. Substituting the bottom ash for K fertilizer offers an emissions saving of 209.6 ton $\mathrm{CO}_{2 \text {-eq }}$ year. Feeding the gasifier-generated electricity into the national grid displaces the emissions produced by electricity generation from fossil fuel in power plants. The 
R1 system could provide $1.7 \times 10^{7} \mathrm{kWh}$ electricity to the grid per year and earn a GHG emissions credit of $-2.5 \times 10^{4}$ ton $\mathrm{CO}_{2-\mathrm{eq}} / \mathrm{year}$, which renders a net environmental GHG mitigation of $2.4 \times 10^{4}$ ton $\mathrm{CO}_{2-\mathrm{eq}} /$ year in $\mathrm{R} 1$.

The GW impact from the construction of the gasification system for M1 is much higher than that of the reference scenarios (R1 and R2). The GW burden from the gasification process emissions is 336.2 ton $\mathrm{CO}_{2-\mathrm{eq}}$ /year, which is only $60 \%$ of that from the combustion process. This is driven by far lower $\mathrm{NO}_{\mathrm{x}}$ emissions for gasification (6 $\mathrm{mg}$ per ton dry biomass) compared to combustion (43.5 mg per ton dry biomass). Indeed, it is commonly agreed that $\mathrm{NO}_{\mathrm{x}}$ emissions are in general not a problem for syngas systems. First, less $\mathrm{NO}_{\mathrm{x}}$ is present in the produced synthetic gas due to its lower operation temperature $\left(<900 \mathrm{C}^{\circ}\right)$ and deficient oxygen condition in gasifier, compared with the combustion process (> $1000 \mathrm{C}^{\circ}$ and sufficient air supply) (Maya et al., 2016). Second, the syngas engine is commonly operated with a lean burn (high air:fuel ratio) to increase efficiency, and the excessive air absorbs heat and lowers the combustion temperature, which reduces the $\mathrm{NO}_{\mathrm{x}}$ formation (Ahrenfeldt et al., 2005). Carbon sequestration by biochar receives a credit of $-1.1 \times 10^{4}$ ton $\mathrm{CO}_{2-\mathrm{eq}}$ /year and plays an important role in alleviating the overall GW impact from the gasification system. M1 realizes the highest net GW mitigation by both displacing grid electricity and producing and sequestering biochar. Compared to R1, the deployment of a M1 system provides yearly GHG emissions mitigation of $5.8 \times 10^{4}$ ton $\mathrm{CO}_{2 \text {-eq. }}$.

In $\mathrm{M} 2_{1}$, it is assumed that a small-scale gasifier is constructed corresponding to budget limitations. The credits received from biochar (-759.0 ton $\mathrm{CO}_{2}$-eq/year) and bottom ash-based fertilizer substitution (-195.6 ton $\mathrm{CO}_{2-\mathrm{eq}} / \mathrm{year}$ ) can fully compensate all the $\mathrm{GHG}$ emissions, leading to a net environmental saving of 222.7 ton $\mathrm{CO}_{2}$-eq/year for $\mathrm{M}_{1}$. The results again show 
that incorporating even a small-scale gasifier in oil palm biomass management can reduce GHG emissions, with a large contribution from biochar production. Overall, the results clearly demonstrate that the gasification systems have three advantages over the mills' current biomass combustion systems: $62 \%$ higher electricity output, less than half of the GHG emissions during thermal conversion, and tremendous benefits of carbon sequestration in the produced biochar.

\subsection{CBA}

\subsubsection{Base case}

The base case results are shown in Table 7 in terms of cost and benefit components for the proposed scenarios. In general, the O\&M cost serves as the largest cost contributor for both the village and mill scenarios, followed by the system cost, mini-grid cost, and kerosene cost. However, under the current household electricity demand, the mini-grid cost overtakes the system cost in V2. The income from electricity sales generally dominates the income from biochar. Under the biochar price of $500 \mathrm{USD} /$ ton and current electricity consumption demands, the systems of V1 and M1 have positive NPVs when the capacity factor is $100 \%$. We also

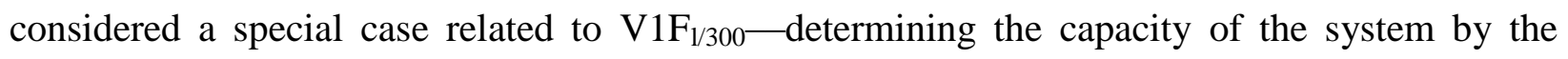
amount of biomass available and the capacity factor is $100 \%$ with electricity consumption corresponding to the current daily household electricity demand $(0.4 \mathrm{kWh})$. In this case, the biochar income overtakes the electricity income and the mean NPV is $1.3 \times 10^{4}$ USD under the biochar prices of $500 \mathrm{USD} / \mathrm{ton}$ and current ET (0.11 USD/kWh). In a similar case for M1, where there is a $100 \%$ capacity factor while the electricity income still corresponds to the consumption 
demands, a mean NPV of $7.8 \times 10^{5}$ USD resulted under the biochar price of 500 USD/ton and current ET (0.11 USD/kWh).

For V2, although the capacity factor is $100 \%$, it still bears a negative NPV, suggesting the impact of economies of scale. The biochar productivity ranges from a few tons to hundreds of tons for villages, and a few tons to thousands of tons for the mill. Despite the lack of robust data on the biochar market in Indonesia, the vast agricultural areas suggests a huge demand in the country for biochar-based agricultural products (e.g., soil conditioner and fertilizer). Existing data from other countries with major economies have shown significant increase on biochar demand worldwide, which will serve to facilitate the international biochar market (Guo et al., 2016).

\subsubsection{Monte Carlo Simulation}

\section{(a) Village - NPV}

The profitability conditions of the system can be described using NPV contours as shown in Figure 6. For V1, it is clear that a relatively high (or low) capacity factor is accompanied by a relatively low (high) ET to maintain the same NPV level. At the capacity factor level corresponding to the current household demand (2.8\%), the ET must be significantly larger than $0.3 \mathrm{kWh}$ to achieve the break-even in the average NPV. Electricity that is too expensive, however, suggests a great financial pressure on the end-users. It is important that the electricity price stays within an affordable price range for consumers. Past experience from India has shown that some gasification-based power generation projects in rural areas closed after few months of operation because the low paying capacity of the end users precluded the economic viability of 
the project (Palit et al., 2011). The monthly net income from oil palm plantations was reported to be around 500 USD/month per household (Feintrenie et al., 2010; Lee et al., 2014). Considering that the electricity bill accounts for, at most, less than 5\% of the income (Wijaya \& Tezuka, 2013), the corresponding ET under the current level of household demand should be less than 2.1 USD/kWh. For the case of villages with 300 households: At a biochar price of $500 \mathrm{USD} / \mathrm{ton}$, the system can reach the NPV break-even point at the current ET level with a capacity factor of around $44 \%$ and a corresponding daily electricity consumption of $6.4 \mathrm{kWh}$. At a biochar price of $2650 \mathrm{USD} / \mathrm{ton}$, the capacity factor would need to be $16 \%$ and the electricity consumption would be $2.3 \mathrm{kWh}$ to reach the break-even point at the current ET level. For the case of villages with 500 households: At a biochar price of $500 \mathrm{USD} / \mathrm{ton}$, the NPV break-even point is at a $38 \%$ capacity factor. With biochar prices at $2650 \mathrm{USD} /$ ton, the 500-household break-even capacity factor is $14 \%$.

Similarly, for V2, a relatively high (or low) household demand is accompanied by a relatively low (high) ET to maintain the same NPV level. In the case of 300 households (500 households), a daily household demand of $2 \mathrm{kWh}(1.8 \mathrm{kWh})$ is required to reach the break-even point in the average NPV at the current ET and highest biochar price. When the ET increases to 0.3 USD/kWh, the break-even of NPV could be achieved at the household demand of $0.8 \mathrm{kWh}(0.6$ $\mathrm{kWh})$ at zero biochar price for the cases of 300 households (500 households). Figure 6 also shows that the larger the number of households considered, the easier for the system to be profitable. The biochar price has a greater impact on the NPV at higher capacity factors (i.e. higher household demands). This is related to the facts that (1) the capacity factor and household 
demand directly affect the biochar production for both V1 and V2, and (2) the relative effect of biochar income to electricity income shrinks at high ET levels.

A high electricity demand, e.g. by introducing additional productive uses, is desirable so that the correspondingly designed system has a better chance of being profitable. The study by (Mangoyana \& Smith, 2011) also indicated that the commercial viability of decentralized systems could be enhanced by integrating the bioenergy production system with other production systems or forming a closed-loop waste production and re-usage system. On the other hand, there is a trend that the household electricity demand will increase with respect to time. (Batih \& Sorapipatana, 2016) showed that the average daily electricity consumption was around $3.4 \mathrm{kWh}$ and $5.4 \mathrm{kWh}$ for the urban households of the lowest (<31 USD) and second lowest (31 - 73.5 USD) monthly income per capita in the major cities of Indonesia. When the household demand in rural areas reaches the urban level for the second lowest income families, the designed V2 system will have a high chance of becoming economically viable under the current ET. Otherwise, significant fiscal incentives are needed to ensure the commercial viability of the designed system under the current ET and demand.

V2 is more financially viable (has a higher NPV) than V1 under the same conditions (i.e. ET and biochar price) because it could achieve the break-even NPV point at significantly lower household demands. The power generation ability of the V2 system may be limited and primarily depends upon expanding the gasification system's operating hours to increase power output (at most, a four time increase with 24 hour per day operation). The V1 system is more flexible and has a greater potential to cover unexpected future power demand increases. Detailed 
relationships between the NPV and ET, capacity factor, and household demand for V1 and V2 could be found in the Supplementary Material (Figures S1 and S2).

\section{(2) Village - LCOE}

The distributions of LCOE for V1 and V2 are shown in Figure 7. The mean and standard deviations of the LCOE distributions decrease with increases in capacity factor (V1) and household demand (V2). The average LCOEs in the V1 scenario are always larger than the current ET, $0.11 \mathrm{USD} / \mathrm{kWh}$, while the average LCOEs in the V2 scenario are smaller than the current ET under the household demand of 5.5 kWh. Blum et al. (2013) estimated the LCOEs of renewable (micro-hydropower and solar PV + battery) and hybrid (renewable + conventional) energy systems. These LCOEs were generally larger than $0.5 \mathrm{USD} / \mathrm{kWh}$, except for the microhydropower-based system (23.4 kW), which had a LCOE less than $0.2 \mathrm{USD} / \mathrm{kWh}$. Hence, under the current household demand, the average LCOE of V2 proposed in this work is less than that of the renewable and hybrid systems proposed by Blum et al. (2013), except for the microhydropower-based system. The necessity of adding a battery to the solar system to provide the power usage at night likely caused the higher LCOEs for the systems proposed by Blum et al. (2013). The LCOE of a stand-alone PV system was reported to be $0.66 \mathrm{USD} / \mathrm{kWh}$ (Veldhuis \& Reinders, 2014), which is higher than that of the V2 system and the V1 system with a capacity factor larger than $10 \%$. The LCOE of grid-connected PV system was $0.17-0.24 \mathrm{USD} / \mathrm{kWh}$ for rural areas (Veldhuis \& Reinders, 2013), which is more competitive compared to V2 under the current household demand, while less competitive under the household demands of 1.9 and 5.5 kWh. A system based on a combination of solar, biomass, and conventional power in remote 
areas of Indonesia had a LCOE of about 0.6 USD/kWh (da Fonseca et al., 2014), which is less competitive compared to the V2 system under the current household demand level (i.e. (a) and (b)). The variation of the LCOE with respect to the household demand for the diesel generator reference case (please see Figure S3 in the Supplementary Material) shows that the LCOE of diesel generator decreases as the household demand increases. Under the same household demand, the average LCOE of V2 is about one-fourth that of the reference scenario, while the average LCOE of V1 is higher than that of the reference scenario, with the difference being reduced with increases in the capacity factor.

(3) Mill - NPV

The contours of mean NPV for M1 and M2 are shown in Figure 8. The contour patterns are similar to those in the village scenarios (Figure 6); yet, a high capacity factor (or mill demand) and ET underpin the system's profitability. Figure 8 (a) shows that M1 will reach the break-even point of the mean NPV at the ET of $0.3 \mathrm{USD} / \mathrm{kWh}$ when the capacity factor is around $25 \%, 20 \%$, and $12 \%$, for the biochar prices of 0,500 , and $2650 \mathrm{USD} /$ ton, respectively. M2 could reach the break-even point at the current ET and electricity demand and at a biochar price higher than 500 USD/ton. M1 will have a positive average NPV at the current ET and zero biochar price if its capacity factor is over $70 \%$. If the biochar price increases to $500 \mathrm{USD} / \mathrm{ton}$, a capacity factor around $44 \%$ (or $18 \%$ for $2650 \mathrm{USD} /$ ton biochar) is needed to reach the break-even point of the average NPV for M1.

The NPV contours of the reference scenarios (R1 and R2) are shown in Figure S8. At the current ET, R1 could not reach the break-even point of the mean NPV, even under a full load 
capacity. When the ET increases to $0.3 \mathrm{USD} / \mathrm{kWh}, \mathrm{R} 1$ will have a positive mean NPV when the capacity factor is larger than $47 \%$. Similarly, R2 remains unprofitable up to a mill demand of $2.0 \times 10^{4} \mathrm{kWh}$ under the current ET. If the ET increases to around $0.24 \mathrm{USD} / \mathrm{kWh}, \mathrm{R} 2$ could reach the break-even point under the current daily demand per household $(0.4 \mathrm{kWh})$.

\section{(4) Mill - LCOE}

The LCOE distributions (Figure 9) indicate that the average and standard deviation of LCOE decreases as the capacity factor increases for M1. The average LCOEs for M1 and M2 are respectively larger and smaller than that of grid-connected PV system $(0.17-0.24 \mathrm{USD} / \mathrm{kWh})$, but the average LCOEs for M1 are smaller than that of stand-alone PV system (0.66 USD/kWh) as reported by Veldhuis \& Reinders (2013). However, the average LCOE decreases to approximately 0.06 when the M1 system operates at a 100\% capacity factor (not shown here), reemphasizing the benefit of feeding electricity into the national grid. The LCOEs of M1 and M2 are smaller than those of V1 and V2 under the current electricity demand conditions of village and mill, respectively.

The average LCOE of R1 (Figure S9 in the Supplementary Material) are smaller than that of M1. Hence, better profitability of M1 than R1 as shown by the contours of mean NPV should be cause by the higher benefit for M1. When the system capacity is determined by the electricity demand of the mill, the LCOE of gasification-based M2 is around 60\% of combustion-based R2. 


\subsubsection{Sensitivity analysis}

To explore the effects of CBA parameters on the NPV for the proposed scenarios (i.e. V1, V2, M1, and M2), sensitivity analysis was conducted based on the design-of-experiments (DOE) (Montgomery, 1991). Six parameters, including the unit cost of the gasification system (A), O\&M cost (B), the overall electrical efficiency (i.e. $C G E \times E F)(\mathrm{C})$, ET (D), the capacity factor for V1 and M1 or electricity demand for V2 and M2 (E), and the biochar price (F), are considered, and thus it is a $2^{6}$ factorial design. In the analysis, the setting of the nominal values is $\mathrm{A}=1500 \mathrm{USD} / \mathrm{kWh}, \mathrm{B}=16.8 \%, \mathrm{C}=24.4 \%, \mathrm{D}=0.11 \mathrm{USD} / \mathrm{kWh}, \mathrm{E}=2.8 \%(\mathrm{~V} 1), \mathrm{E}=7.4 \%(\mathrm{M} 1)$, $\mathrm{E}=0.4 \mathrm{kWh}(\mathrm{V} 2), \mathrm{E}=11000 \mathrm{kWh}(\mathrm{M} 2), \mathrm{F}=250 \mathrm{USD} / \mathrm{ton}$, and the low and high levels of the factors are $-20 \%$ and $+20 \%$ of the nominal values. The main effects and interactions are calculated by

$$
E f f=\frac{1}{2^{5}} \sum_{j=1}^{64} \pm \mathrm{NPV}_{i, j}
$$

where \pm corresponds to the (+/-) signs of each main effect and interaction for each response. More details on the methods could be found in the study by You et al. (2016). The main effects and interactions of the factors are estimated and their significance is examined using a normal probability plot (Figure 10) wherein, if a factor or an interaction has more significant effect on the NPV, it will deviate farther away from the straight line.

Figure 10 shows that V1, V2, and M1 have similar significant interactions of the factors which are based on $\mathrm{E}$ (capacity factor or electricity demand) and $\mathrm{F}$ (biochar price). These suggest the critical roles of biochar marketing and electricity demand in the commercial viability of these scenarios. For M2, the biochar price (F) and some of its interactions with factors B to D play a moderate role in M2, which suggests that the commercial viability of the M2 system should be 
relatively sensitive to the variation of biochar price, compared to the other scenarios. For V1 and M1, the most significant main effects are A (cost of gasification system) and C (overall electrical efficiency). For V2 and M2, the most significant main effects are A (cost of gasification system) and D (ET), followed by B (O\&M cost) and C (overall electrical efficiency) playing a more moderate role. This means that the cost of the gasification system is always a critical determinant of the system's profitability. This is coincident with a recent survey by Aghamohammadi et al. (2016), which showed that capital investment was one of the most important factors in the decisions of mill owners to adopt oil palm waste-based renewable energy business, followed by the attractiveness of electricity tariff and biomass supply chain consistency. Sovacool \& Bulan (2012) also found that the tariff level and capital expenditure critically affected the performance of a renewable energy development plan. For the systems with the capacity determined by the amount of available biomass (V1 and M1), more focus should be put to enhance their overall electrical efficiency, whereas adjusting the ET would be desirable for the systems with the capacity determined by the electricity demands. For a large-scale system where an integrated gasification combined cycle is suitable, the net electricity efficiencies could reach up to $30-40 \%$ (Belgiorno et al., 2003). The adjustment of ET will be subjected to the paying capacity of the consumers. Past experiences from India have shown that some gasification-based power generation projects in rural areas closed after few months of operation due to the low paying capacity of the end users (Palit et al., 2011). 


\subsection{Overall Discussion}

Community participation and support are critical for the success of decentralized bioenergy systems (Mangoyana \& Smith, 2011). The proposed scenarios in this work pay special attention to the electricity demands of affiliated communities and serve to enhance the communities' selfreliance. This study works to design decentralized gasification systems with a target to cater to the demands of all the stakeholders (i.e., consumers, investors, and policymakers), and is thus of great practical value for guiding the deployment of bioenergy systems in rural areas. In the future, the hybrid LCA- and CBA-based evaluation scheme could be extended to the cases of various other biomass types and regions or countries for developing a global view concerning the economic and environmental impacts of decentralized gasification systems for biomass waste disposal.

Utilizing oil palm biomass waste for bioenergy could effectively reduce the GHG emissions and benefit the environmental sustainability of the region. Shi \& Yamaguchi (2014) showed that most of the $\mathrm{CO}_{2}$ emissions in Indonesia was coming from biomass burning. Note that the external cost of the reduction of GHG is not accounted for in the CBA. However, under a carbon price of 1.34 (Clean Development Mechanism market) or 9.20 (voluntary carbon market) USD/ton $\mathrm{CO}_{2 \text {-eq. }}$ (Sparrevik et al., 2014), the yearly external benefit by switching from diesel generator $\left(D_{1}\right)$ to gasification $\left(V_{1 / 300}\right)$ is 9667.3 or $64621.3 \mathrm{USD}$, which increases the average NPV from $-2.2 \times 10^{4}$ USD to $6.6 \times 10^{4}$ USD or $5.6 \times 10^{5}$ USD at the biochar price of $2650 \mathrm{USD} /$ ton.

The LCA results of this work is consistent with that of Yang \& Chen (2014) in terms of the largest GHG-emitting components of a gasification project, i.e. the operation and construction stages corresponding to the consumption of crop residue, electricity and steel. As mentioned 
above, the plantation of oil palm biomass is outside the LCA boundary in this work, but may serve as an important GHG emissions source for a cradle-to-gate LCA boundary. For example, Silalertruksa et al. (2013) found that the plantation of rice straw accounts for around 50\% of the total GHG emissions of rice straw bio-DME production via gasification. The production of cereal biomass was also found to dominate the GW impact for a decentralized, combustion-based plant (Sastre et al., 2014). Logistics (transportation) of rice straw was found to account for almost $50 \%$ of the GW impact for a gasification-based, large-scale polygeneration (power, ethanol, heating and cooling) plant (Jana \& De, 2017). Nguyen et al. (2013) reported that the gasification of straw had a $\mathrm{GW}$ impact of $80 \mathrm{~g} \mathrm{CO}_{2 \text {-eq }}$ per $\mathrm{kWh}$ of electricity, which is smaller than that of $V 1_{1 / 300}$ and $V 1_{1 / 500}$, but higher than other village scenarios in Figure 4. Their LCA also considered the impacts of the removal, collection, pre-processing, and transportation of straw, which played a major role in the calculated GW impact. Similar to our study, Nguyen et al. (2013) also found that the more environmentally friendly nature of gasification, relative to combustion, was contributed to by its higher electricity efficiency, lower exhaust emissions, and higher recalcitrant content in the solid residue.

In addition to their environmental and economic viability, the successful implementation of decentralized power systems in rural areas is critically affected by policy formulation and fiscal incentives (Kaundinya et al., 2009; Sparrevik et al., 2014). Policy formulation is important in (1) effective dissemination and operation of the systems, and (2) developing education mechanisms for rural communities to understand the importance of renewable energy systems in creating employment, increasing incomes, and improving living standards (ADB, 2016b). (Kardooni et al., 2016) found that public acceptance of renewable energy technology is an essential element in 
the dissemination and development of renewable energy resources. The CBA shows that, under the current ET and demands, the proposed scenarios could hardly be economically viable unless the electricity could be fed into the national grid for M1 and there is a high biochar price (e.g., 500 USD/ton) for M2. As a result, innovative fiscal and financial incentives should be developed to finance the relatively large capital costs, initially with acceptable loans, and increase the commerciality of the market. Indonesia has introduced a feed-in-tariff (FiT) scheme, with the aim of increasing the share of renewable energy in the country's total energy mix (MEMR, 2017). The FiT scheme allows renewable energy developers to have a guaranteed benefit by exporting electricity to the main power grid at a fixed, stable price. However, in Indonesia, the lack of appropriate transmission line infrastructure makes electricity export to the main grid difficult; the FiT policy could thus hardly be enjoyed for the mills without increased access to the national grid. In 2013, the government proposed a ceiling price region to facilitate the development of solar PV power by attracting IPP (Independent Power Provider) investment (Hirsch et al., 2015). Setting a similar ceiling price for bioenergy could potentially make the proposed scenarios economically viable, even under current market conditions. On the whole, a benign interaction between government, small-holding farmers, and companies needs to be maintained for the ultimate success of the business and industry.

\section{CONCLUSIONS}

Gasification is a technologically feasible means for the disposal of oil palm biomass waste in Indonesia, with the ability to relieve the country's over-reliance on fossil fuel-based power generation and facilitate the electrification of its rural areas. Overall, under the current ET and 
electricity demand, V2 (village sub-scenario with the capacity determined by the village electricity demand) is superior to V1 (village sub-scenario with the capacity determined by the amount of biomass available), in terms of both GW impact and economics, unless significantly more biochar is produced in the case of V1. For the case of a mill, M1 (mill sub-scenario with the capacity determined by the amount of biomass available) is both environmentally and financially better than M2 (mill sub-scenario with the capacity determined by the mill electricity demand) when the national grid is accessible or significantly more biochar is produced. Under the current daily demand per household $(0.4 \mathrm{kWh})$, deploying the V2 system in $10^{4}$ villages with 500 households each could mitigate up to 17.9 thousand tons of $\mathrm{CO}_{2 \text {-eq }}$ per year compared to the current diesel-based practice. If the electricity could be fed into the national grid, the M1 system with $100 \%$ capacity factor provides yearly GHG emissions mitigation of $5.8 \times 10^{4}$ ton $\mathrm{CO}_{2 \text {-eq, }}$ compared to R1. For V2, daily household demands of 2 and $1.8 \mathrm{kWh}$ are required to achieve the break-even of the average NPV at the current ET $(0.11 \mathrm{kWh})$ and the biochar price of 2650 USD/ton for the cases of 300 and 500 households, respectively. In terms of the average NPV, M1 will be economically feasible if the electricity can be fed into the national grid, while M2 will be economically feasible at the biochar price of $500 \mathrm{USD} /$ ton. The average LCOE of V2 is about one-fourth that of the diesel generator-based reference scenario, while the average LCOE of V1 is larger than that of the reference scenario. The average LCOE of M1 decreases to around $0.06 \mathrm{USD} / \mathrm{kWh}$ when the full load capacity is reached. Sensitivity analysis shows that the most significant main effects on the NPV are the cost of the gasification system and the overall electrical efficiency. 


\section{ACKNOWLEDGEMENT}

The authors acknowledge the funding support from the National Research Foundation (NRF),

Prime Minister's Office, Singapore under its Campus for Research Excellence and Technological

Enterprise (CREATE) program. Grant Number R-706-001-101-281, National University of

Singapore.

\section{REFERENCES}

Abe, H., Katayama, A., Sah, B.P., Toriu, T., Samy, S., Pheach, P., Adams, M.A., Grierson, P.F. 2007. Potential for rural electrification based on biomass gasification in Cambodia. Biomass and Bioenergy, 31(9), 656-664.

Adaramola, M.S., Agelin-Chaab, M., Paul, S.S. 2014. Analysis of hybrid energy systems for application in southern Ghana. Energy Conversion and Management, 88, 284-295.

ADB. Achieving universal electricity access in indonesia: https://www.adb.org/sites/default/files/publication/182314/achieving-electricity-access-ino.pdf; [accessed at April-12-2017].

ADB. Fossil fuel subsidies in Indonesia trends ,impacts and reforms: https://www.adb.org/sites/default/files/publication/175444/fossil-fuel-subsidies-indonesia.pdf; [accessed at April-12-2017].

ADB. $\quad$ https://www.adb.org/sites/default/files/institutional-document/189713/ino-energy-asr.pdf: https://www.adb.org/sites/default/files/institutional-document/189713/ino-energy-asr.pdf; [accessed at April-20-2017].

Aghamohammadi, N., Reginald, S.S., Shamiri, A., Zinatizadeh, A.A., Wong, L.P., Nik Sulaiman, N.M.B. 2016. An investigation of sustainable power generation from oil palm biomass: a case study in Sarawak. Sustainability, 8(5), 416.

Ahmed, M.B., Zhou, J.L., Ngo, H.H., Guo, W. 2016. Insight into biochar properties and its cost analysis. Biomass and Bioenergy, 84, 76-86.

Ahmed, T., Mekhilef, S., Shah, R., Mithulananthan, N., Seyedmahmoudian, M., Horan, B. 2017. ASEAN power grid: A secure transmission infrastructure for clean and sustainable energy for South-East Asia. Renewable and Sustainable Energy Reviews, 67, 1420-1435.

Ahrenfeldt, J., Jensen, T.K., Henriksen, U., Schramm, J. 2005. Investigation of continuous gas engine CHP operation on biomass producer gas. SAE technical paper. 0148-7191.

Arena, U., Di Gregorio, F., Santonastasi, M. 2010. A techno-economic comparison between two design configurations for a small scale, biomass-to-energy gasification based system. Chemical Engineering Journal, 162(2), 580-590.

Ariffin, M.A., Mahmood, W.M.F.W., Harun, Z., Mohamed, R. 2016a. Medium-scale gasification of oil palm empty fruit bunch for power generation. Journal of Material Cycles and Waste Management, 1-9.

Ariffin, M.A., Wan Mahmood, W.M.F., Mohamed, R., Mohd Nor, M.T. 2016b. Performance of oil palm kernel shell gasification using a medium-scale downdraft gasifier. International Journal of Green Energy, 13(5), 513-520. 
Atnaw, S.M., Kueh, S.C., Sulaiman, S.A. 2014a. Study on tar generated from downdraft gasification of oil palm fronds. The Scientific World Journal, 2014.

Atnaw, S.M., Sulaiman, S.A., Yusup, S. 2014b. Influence of fuel moisture content and reactor temperature on the calorific value of syngas resulted from gasification of oil palm fronds. The Scientific World Journal, 2014.

Atnaw, S.M., Sulaiman, S.A., Yusup, S. 2013. Syngas production from downdraft gasification of oil palm fronds. Energy, 61, 491-501.

Azam, M., Khan, A.Q., Bakhtyar, B., Emirullah, C. 2015. The causal relationship between energy consumption and economic growth in the ASEAN-5 countries. Renewable and Sustainable Energy Reviews, 47, 732-745.

Aziz, M., Kurniawan, T., Oda, T., Kashiwagi, T. 2017. Advanced power generation using biomass wastes from palm oil mills. Applied Thermal Engineering, 114, 1378-1386.

Balamurugan, P., Ashok, S., Jose, T. 2009. Optimal operation of biomass/wind/PV hybrid energy system for rural areas. International Journal of Green Energy, 6(1), 104-116.

Barrett, S.R., Yim, S.H., Gilmore, C.K., Murray, L.T., Kuhn, S.R., Tai, A.P., Yantosca, R.M., Byun, D.W., Ngan, F., Li, X. 2012. Public health, climate, and economic impacts of desulfurizing jet fuel. Environmental Science \& Technology, 46(8), 4275-4282.

Batih, H., Sorapipatana, C. 2016. Characteristics of urban households' electrical energy consumption in Indonesia and its saving potentials. Renewable and Sustainable Energy Reviews, 57, 1160-1173.

Belgiorno, V., De Feo, G., Della Rocca, C., Napoli, R. 2003. Energy from gasification of solid wastes. Waste Management, 23(1), 1-15.

Blum, N.U., Wakeling, R.S., Schmidt, T.S. 2013. Rural electrification through village grids-Assessing the cost competitiveness of isolated renewable energy technologies in Indonesia. Renewable and Sustainable Energy Reviews, 22, 482-496.

Bocci, E., Sisinni, M., Moneti, M., Vecchione, L., Di Carlo, A., Villarini, M. 2014. State of art of small scale biomass gasification power systems: a review of the different typologies. Energy Procedia, 45, 247-256.

Carter, S., Shackley, S., Sohi, S., Suy, T.B., Haefele, S. 2013. The impact of biochar application on soil properties and plant growth of pot grown lettuce (Lactuca sativa) and cabbage (Brassica chinensis). Agronomy, 3(2), 404-418.

Chakrabarti, S., Chakrabarti, S. 2002. Rural electrification programme with solar energy in remote region-a case study in an island. Energy Policy, 30(1), 33-42.

Channiwala, S., Parikh, P. 2002. A unified correlation for estimating HHV of solid, liquid and gaseous fuels. Fuel, 81(8), 1051-1063.

Chiew, Y.L., Iwata, T., Shimada, S. 2011. System analysis for effective use of palm oil waste as energy resources. Biomass and Bioenergy, 35(7), 2925-2935.

Choppala, G., Bolan, N., Megharaj, M., Chen, Z., Naidu, R. 2012. The influence of biochar and black carbon on reduction and bioavailability of chromate in soils. Journal of Environmental Quality, 41(4), 1175-1184.

da Fonseca, M.B., Poganietz, W.-R., Gehrmann, H.-J. 2014. Environmental and economic analysis of SolComBio concept for sustainable energy supply in remote regions. Applied Energy, 135, 666674.

Doka, G. 2014. Updates to life cycle inventories of waste treatment services-part II: waste incineration. Doka Life Cycle Assessments, Zürich, Switzerland.

Dufo-López, R., Bernal-Agustín, J.L., Yusta-Loyo, J.M., Domínguez-Navarro, J.A., Ramírez-Rosado, I.J., Lujano, J., Aso, I. 2011. Multi-objective optimization minimizing cost and life cycle emissions of stand-alone PV-wind-diesel systems with batteries storage. Applied Energy, 88(11), 4033-4041. 
Eksi, G., Karaosmanoglu, F. 2017. Combined bioheat and biopower: A technology review and an assessment for Turkey. Renewable and Sustainable Energy Reviews, 73, 1313-1332.

Erlich, C., Fransson, T.H. 2011. Downdraft gasification of pellets made of wood, palm-oil residues respective bagasse: experimental study. Applied Energy, 88(3), 899-908.

Ertürk, M. 2012. The evaluation of feed-in tariff regulation of Turkey for onshore wind energy based on the economic analysis. Energy Policy, 45, 359-367.

Feintrenie, L., Chong, W.K., Levang, P. 2010. Why do farmers prefer oil palm? Lessons learnt from Bungo district, Indonesia. Small-scale forestry, 9(3), 379-396.

Field, J.L., Tanger, P., Shackley, S.J., Haefele, S.M. 2016. Agricultural residue gasification for low-cost, low-carbon decentralized power: An empirical case study in Cambodia. Applied Energy, 177, 612-624.

François, J., Abdelouahed, L., Mauviel, G., Patisson, F., Mirgaux, O., Rogaume, C., Rogaume, Y., Feidt, M., Dufour, A. 2013. Detailed process modeling of a wood gasification combined heat and power plant. Biomass and Bioenergy, 51, 68-82.

Galinato, S.P., Yoder, J.K., Granatstein, D. 2011. The economic value of biochar in crop production and carbon sequestration. Energy Policy, 39(10), 6344-6350.

Gatto, M., Wollni, M., Asnawi, R., Qaim, M. 2017. Oil palm boom, contract farming, and rural economic development: Village-level evidence from Indonesia. World Development.

González-García, S., Iribarren, D., Susmozas, A., Dufour, J., Murphy, R.J. 2012. Life cycle assessment of two alternative bioenergy systems involving Salix spp. biomass: Bioethanol production and power generation. Applied Energy, 95, 111-122.

González, A., Riba, J.-R., Puig, R., Navarro, P. 2015. Review of micro-and small-scale technologies to produce electricity and heat from Mediterranean forests' wood chips. Renewable and Sustainable Energy Reviews, 43, 143-155.

Guangul, F., Sulaiman, S., Ramli, A. 2013. Temperature profile and producer gas composition of high temperature air gasification of oil palm fronds. IOP Conference Series: Earth and Environmental Science. IOP Publishing. pp. 012067.

Guangul, F.M., Sulaiman, S.A., Ramli, A. 2012. Gasifier selection, design and gasification of oil palm fronds with preheated and unheated gasifying air. Bioresource Technology, 126, 224-232.

Guillaume, T., Damris, M., Kuzyakov, Y. 2015. Losses of soil carbon by converting tropical forest to plantations: erosion and decomposition estimated by $\delta 13 \mathrm{C}$. Global change biology, 21(9), 35483560 .

Guo, M., Uchimiya, S.M., He, Z. 2016. Agricultural and environmental applications of biochar: Advances and barriers. Soil Science Society of America, Inc.

Hansen, V., Müller-Stöver, D., Ahrenfeldt, J., Holm, J.K., Henriksen, U.B., Hauggaard-Nielsen, H. 2015. Gasification biochar as a valuable by-product for carbon sequestration and soil amendment. Biomass and Bioenergy, 72, 300-308.

Hirsch, B., Burman, K., Davidson, C., Elchinger, M., Hardison, R., Karsiwulan, D., Castermans, B. 2015. Sustainable Energy in Remote Indonesian Grids: Accelerating Project Development. National Renewable Energy Laboratory.

Ho, W.S., Khor, C.S., Hashim, H., Lim, J.S., Ashina, S., Herran, D.S. 2015. Optimal operation of a distributed energy generation system for a sustainable palm oil-based eco-community. Clean Technologies and Environmental Policy, 17(6), 1597-1617.

i Canals, L.M., Muñoz, I., McLaren, S., Brandão, M. 2007. LCA methodology and modelling considerations for vegetable production and consumption. CES Working Paper 02/07.

Itten, R., Frischknecht, R., Stucki, M., Scherrer, P., Psi, I. 2012. Life cycle inventories of electricity mixes and grid.

Jana, K., De, S. 2017. Environmental impact of biomass based polygeneration-A case study through life cycle assessment. Bioresource Technology, 227, 256-265. 
Jarungthammachote, S., Dutta, A. 2008. Equilibrium modeling of gasification: Gibbs free energy minimization approach and its application to spouted bed and spout-fluid bed gasifiers. Energy Conversion and Management, 49(6), 1345-1356.

Jenkins, B.M. 1997. A comment on the optimal sizing of a biomass utilization facility under constant and variable cost scaling. Biomass and Bioenergy, 13(1-2), 1-9.

Jungbluth, N., Chudacoff, M., Dauriat, A., Dinkel, F., Doka, G., Faist Emmenegger, M., Gnansounou, E., Kljun, N., Schleiss, K., Spielmann, M. 2007. Life cycle inventories of bioenergy. Final report ecoinvent data v2. $0,17$.

Kardooni, R., Yusoff, S.B., Kari, F.B. 2016. Renewable energy technology acceptance in Peninsular Malaysia. Energy Policy, 88, 1-10.

Kaundinya, D.P., Balachandra, P., Ravindranath, N. 2009. Grid-connected versus stand-alone energy systems for decentralized power-A review of literature. Renewable and Sustainable Energy Reviews, 13(8), 2041-2050.

Lahijani, P., Zainal, Z. 2014. Fluidized bed gasification of palm empty fruit bunch using various bed materials. Energy Sources, Part A: Recovery, Utilization, and Environmental Effects, 36(22), 2502-2510.

Lee, J.S.H., Ghazoul, J., Obidzinski, K., Koh, L.P. 2014. Oil palm smallholder yields and incomes constrained by harvesting practices and type of smallholder management in Indonesia. Agronomy for Sustainable Development, 34(2), 501-513.

Lehmann, J., Gaunt, J., Rondon, M. 2006. Bio-char sequestration in terrestrial ecosystems-a review. Mitigation and Adaptation Strategies for Global Change, 11(2), 395-419.

Liu, X., Zhang, A., Ji, C., Joseph, S., Bian, R., Li, L., Pan, G., Paz-Ferreiro, J. 2013. Biochar's effect on crop productivity and the dependence on experimental conditions-a meta-analysis of literature data. Plant and Soil, 373(1-2), 583-594.

Mahmood, W.M.F.W., Ariffin, M., Harun, Z., Ishak, N., Ghani, J.A., Ab Rahman, M.N. 2015. Characterisation and potential use of biochar from gasified oil palm wastes. Journal of Engineering Science and Technology, 10(Spec. Issue on 4th International Technical Conference (ITC) 2014), 45-54.

Malek, A.A., Hasanuzzaman, M., Rahim, N.A., Al Turki, Y.A. 2017. Techno-economic analysis and environmental impact assessment of a $10 \mathrm{MW}$ biomass-based power plant in Malaysia. Journal of Cleaner Production, 141, 502-513.

Mangoyana, R.B., Smith, T.F. 2011. Decentralised bioenergy systems: A review of opportunities and threats. Energy Policy, 39(3), 1286-1295.

Manioğlu, G., Yılmaz, Z. 2006. Economic evaluation of the building envelope and operation period of heating system in terms of thermal comfort. Energy and Buildings, 38(3), 266-272.

Martínez, J.D., Mahkamov, K., Andrade, R.V., Lora, E.E.S. 2012. Syngas production in downdraft biomass gasifiers and its application using internal combustion engines. Renewable Energy, 38(1), 1-9.

Maschowski, C., Zangna, M.C., Trouvé, G., Gieré, R. 2016. Bottom ash of trees from Cameroon as fertilizer. Applied Geochemistry, 72, 88-96.

Maya, D.M.Y., Sarmiento, A.L.E., de Sales, C.A.V.B., Oliveira, E.E.S.L., Andrade, R. 2016. Gasification of Municipal Solid Waste for Power Generation in Brazil, a Review of Available Technologies and Their Environmental Benefits. J. Chem, 10, 249-255.

Mazzola, S., Astolfi, M., Macchi, E. 2016. The potential role of solid biomass for rural electrification: A techno economic analysis for a hybrid microgrid in India. Applied Energy, 169, 370-383.

MEMR, M.o.E.a.M.R. Feed in Tariff: http://ebtke.esdm.go.id/regulation/9/feed.in.tariff; [accessed at April-07-2017]. 
Meyer, S., Glaser, B., Quicker, P. 2011. Technical, economical, and climate-related aspects of biochar production technologies: a literature review. Environmental Science \& Technology, 45(22), 94739483.

Moghadam, R.A., Yusup, S., Uemura, Y., Chin, B.L.F., Lam, H.L., Al Shoaibi, A. 2014. Syngas production from palm kernel shell and polyethylene waste blend in fluidized bed catalytic steam co-gasification process. Energy, 75, 40-44.

Mohammed, M., Salmiaton, A., Azlina, W.W., Amran, M.M., Fakhru'l-Razi, A. 2011. Air gasification of empty fruit bunch for hydrogen-rich gas production in a fluidized-bed reactor. Energy Conversion and Management, 52(2), 1555-1561.

Montgomery, D.C. 1991. Design and analysis of experiments.

$\mathrm{Ng}$, D.K., Ng, R.T. 2013. Applications of process system engineering in palm-based biomass processing industry. Current Opinion in Chemical Engineering, 2(4), 448-454.

Nguyen, T.L.T., Hermansen, J.E., Nielsen, R.G. 2013. Environmental assessment of gasification technology for biomass conversion to energy in comparison with other alternatives: the case of wheat straw. Journal of Cleaner Production, 53, 138-148.

Ogi, T., Nakanishi, M., Fukuda, Y., Matsumoto, K. 2013. Gasification of oil palm residues (empty fruit bunch) in an entrained-flow gasifier. Fuel, 104, 28-35.

Palit, D., Malhotra, R., Kumar, A. 2011. Sustainable model for financial viability of decentralized biomass gasifier based power projects. Energy Policy, 39(9), 4893-4901.

Paltseva, J., Searle, S., Malins, C. 2016. Potential for advanced biofuel production from palm residues in Indonesia, Washington, DC: The International Council on Clean Transportation. Retrieved from http://www. theicct. org/advanced-biofuel-productionfrom-palm-residues-indonesia.

Paoli, G., Schweithelm, J., Gillespie, P., Kurniawan, Y., Aurora, L., Harjanthi, R. 2014. Best management practices in the Indonesian palm oil industry: Case studies. Daemeter Consulting: Bogor, Indonesia, 9.

Pauli, N., Donough, C., Oberthür, T., Cock, J., Verdooren, R., Abdurrohim, G., Indrasuara, K., Lubis, A., Dolong, T., Pasuquin, J. 2014. Changes in soil quality indicators under oil palm plantations following application of 'best management practices' in a four-year field trial. Agriculture, Ecosystems \& Environment, 195, 98-111.

Pode, R., Diouf, B., Pode, G. 2015. Sustainable rural electrification using rice husk biomass energy: A case study of Cambodia. Renewable and Sustainable Energy Reviews, 44, 530-542.

Rodríguez-Fernández, J., Lapuerta, M., Sánchez-Valdepeñas, J. 2017. Regeneration of diesel particulate filters: Effect of renewable fuels. Renewable Energy, 104, 30-39.

SA, S., Atnaw, S.M., AO, M. 2015. Feasibility study of gasification of oil palm fronds. Journal of Mechanical Engineering and Sciences, 9, 1744-1757.

Samiran, N.A., Jaafar, M.N.M., Ng, J.-H., Lam, S.S., Chong, C.T. 2016. Progress in biomass gasification technique-With focus on Malaysian palm biomass for syngas production. Renewable and Sustainable Energy Reviews, 62, 1047-1062.

Sastre, C., Maletta, E., González-Arechavala, Y., Ciria, P., Santos, A., del Val, A., Pérez, P., Carrasco, J. 2014. Centralised electricity production from winter cereals biomass grown under centralnorthern Spain conditions: global warming and energy yield assessments. Applied Energy, 114, 737-748.

Shi, Y., Yamaguchi, Y. 2014. A high-resolution and multi-year emissions inventory for biomass burning in Southeast Asia during 2001-2010. Atmospheric Environment, 98, 8-16.

Silalertruksa, T., Gheewala, S.H., Sagisaka, M., Yamaguchi, K. 2013. Life cycle GHG analysis of rice straw bio-DME production and application in Thailand. Applied Energy, 112, 560-567.

Sovacool, B.K., Bulan, L. 2012. Energy security and hydropower development in Malaysia: The drivers and challenges facing the Sarawak Corridor of Renewable Energy (SCORE). Renewable Energy, 40(1), 113-129. 
Sparrevik, M., Lindhjem, H., Andria, V., Fet, A.M., Cornelissen, G. 2014. Environmental and socioeconomic impacts of utilizing waste for biochar in rural areas in Indonesia-a systems perspective. Environmental Science \& Technology, 48(9), 4664-4671.

Sultana, A., Kumar, A., Harfield, D. 2010. Development of agri-pellet production cost and optimum size. Bioresource Technology, 101(14), 5609-5621.

Sung, C.T.B. Availability, use, and removal of oil palm biomass in Indonesia: http://www.theicct.org/sites/default/files/publications/Teh_palm\%20residues_final.pdf; [accessed at April-12-2017].

Suramaythangkoor, T., Gheewala, S.H. 2010. Potential alternatives of heat and power technology application using rice straw in Thailand. Applied Energy, 87(1), 128-133.

Thangavelu, S.R., Nutkani, I.U., Hwee, C.M., Myat, A., Khambadkone, A. 2015. Integrated electrical and thermal grid facility-testing of future microgrid technologies. Energies, 8(9), 10082-10105.

Veldhuis, A., Reinders, A. 2014. Potential and cost-effectiveness of off-grid PV systems in Indonesia-An evaluation on a provincial level. Photovoltaic Specialist Conference (PVSC), 2014 IEEE 40th. IEEE. pp. 3562-3567.

Veldhuis, A., Reinders, A. 2013. Reviewing the potential and cost-effectiveness of grid-connected solar PV in Indonesia on a provincial level. Renewable and Sustainable Energy Reviews, 27, 315-324.

Vijaya, S., Ma, A., Choo, Y., Nik Meriam, N. 2008. Life cycle inventory of the production of crude palm oil-a gate to gate case study of 12 palm oil mills. Journal of Oil Palm Research, 20(June), 484494.

Wang, Z., Lei, T., Yang, M., Li, Z., Qi, T., Xin, X., He, X., Ajayebi, A., Yan, X. 2017. Life cycle environmental impacts of cornstalk briquette fuel in China. Applied Energy, 192, 83-94.

Wijaya, M.E., Tezuka, T. 2013. A comparative study of households' electricity consumption characteristics in Indonesia: A techno-socioeconomic analysis. Energy for Sustainable Development, 17(6), 596-604.

Wiloso, E.I., Bessou, C., Heijungs, R. 2015. Methodological issues in comparative life cycle assessment: treatment options for empty fruit bunches in a palm oil system. The International Journal of Life Cycle Assessment, 20(2), 204-216.

Withers, M.R., Malina, R., Gilmore, C.K., Gibbs, J.M., Trigg, C., Wolfe, P.J., Trivedi, P., Barrett, S.R. 2014. Economic and environmental assessment of liquefied natural gas as a supplemental aircraft fuel. Progress in Aerospace Sciences, 66, 17-36.

Yang, H., Yan, R., Chen, H., Lee, D.H., Liang, D.T., Zheng, C. 2006. Pyrolysis of palm oil wastes for enhanced production of hydrogen rich gases. Fuel Processing Technology, 87(10), 935-942.

Yang, J., Chen, B. 2014. Global warming impact assessment of a crop residue gasification project-a dynamic LCA perspective. Applied Energy, 122, 269-279.

You, S., Wang, W., Dai, Y., Tong, Y.W., Wang, C.-H. 2016. Comparison of the co-gasification of sewage sludge and food wastes and cost-benefit analysis of gasification-and incineration-based waste treatment schemes. Bioresource Technology, 218, 595-605.

Yuliansyah, A.T., Hirajima, T. 2009. Development of the Indonesian palm oil industry and utilization of solid waste. Journal of the Mining and Materials Processing Institute of Japan, 125(12), 583589.

Yusoff, S. 2006. Renewable energy from palm oil-innovation on effective utilization of waste. Journal of Cleaner Production, 14(1), 87-93. 
Table 1. Production of oil palm biomass in Indonesia (Paltseva et al., 2016; Sung, 2016).

\begin{tabular}{ccc}
\hline & Oil palm biomass & Production $\left(\right.$ dry ton $\left.^{-1} \mathrm{hr}^{-1}\right)$ \\
\hline \multirow{2}{*}{ Field biomass } & OPF & 11 \\
& OPT & 2.8 \\
Mill processing & EFB & 1.6 \\
biomass & PKS & 1.1 \\
& PMF & 1.7 \\
\hline
\end{tabular}


Table 2. A comparison of scenario considerations.

\begin{tabular}{|c|c|c|c|c|}
\hline & Symbol & $\begin{array}{c}\text { System capacity } \\
\text { designation }\end{array}$ & Electricity generation & National grid \\
\hline \multirow{3}{*}{ Village } & V1 & $\begin{array}{c}\text { Amount of } \\
\text { available biomass }\end{array}$ & $\begin{array}{c}\text { Satisfying village } \\
\text { demand }\end{array}$ & No \\
\hline & $\mathrm{V} 2$ & $\begin{array}{c}\text { Daily village } \\
\text { electricity } \\
\text { demand }\end{array}$ & $\begin{array}{c}\text { Satisfying village } \\
\text { demand }\end{array}$ & No \\
\hline & $\mathrm{D}^{\#}$ & $\begin{array}{l}\text { Daily village } \\
\text { electricity } \\
\text { demand }\end{array}$ & $\begin{array}{c}\text { Satisfying village } \\
\text { demand }\end{array}$ & No \\
\hline \multirow{4}{*}{ Mill } & M1 & $\begin{array}{c}\text { Amount of } \\
\text { available biomass }\end{array}$ & $\begin{array}{l}\text { Satisfying mill demand } \\
\text { or } 100 \% \text { capacity factor } \\
\text { with electricity fed into } \\
\text { the grid }\end{array}$ & $\mathrm{No} / \mathrm{Yes}$ \\
\hline & M2 & $\begin{array}{l}\text { Daily mill } \\
\text { electricity } \\
\text { demand }\end{array}$ & Satisfying mill demand & No \\
\hline & $\mathrm{R} 1^{\&}$ & $\begin{array}{c}\text { Amount of } \\
\text { available biomass }\end{array}$ & $\begin{array}{l}\text { Satisfying mill demand } \\
\text { or } 100 \% \text { capacity factor } \\
\text { with electricity fed into } \\
\text { the grid }\end{array}$ & $\mathrm{No} / \mathrm{Yes}$ \\
\hline & $\mathrm{R} 2$ & $\begin{array}{l}\text { Daily mill } \\
\text { electricity } \\
\text { demand }\end{array}$ & Satisfying mill demand & No \\
\hline
\end{tabular}

\# ' $\mathrm{D}$ ' denotes the diesel generator-based reference scenario for the case of village.

$\&$ ' $\mathrm{R}$ ' denotes the boiler combustion-based reference scenario for the case of mill. 
Table 3. Chemical compositions of oil palm biomass.

\begin{tabular}{|c|c|c|c|c|c|c|c|}
\hline \multicolumn{2}{|c|}{ Oil palm biomass } & OPF & PKS & EFB & EFB & OPT & $\overline{\mathrm{PMF}}$ \\
\hline \multirow{3}{*}{$\begin{array}{l}\text { Proximate } \\
\text { analysis } \\
\text { (wt.\% dry } \\
\text { basis) }\end{array}$} & $\begin{array}{l}\text { Volatile } \\
\text { matter }\end{array}$ & 85.1 & 87.82 & 87.37 & 83.5 & 75.20 & 68.8 \\
\hline & $\begin{array}{l}\text { Fixed } \\
\text { carbon }\end{array}$ & 11.5 & 16.12 & 9.47 & 15.2 & 10.04 & 15.2 \\
\hline & Ash & 3.4 & 4.44 & 3.16 & 1.3 & 4.79 & 10.2 \\
\hline \multirow{5}{*}{$\begin{array}{l}\text { Ultimate } \\
\text { analysis } \\
\text { (wt.\% dry } \\
\text { basis) }\end{array}$} & Carbon & 42.4 & 49.65 & 42.08 & 44.58 & 41.88 & 43.19 \\
\hline & Hydrogen & 5.8 & 6.13 & 7 & 4.53 & 5.98 & 5.24 \\
\hline & Oxygen & 48.2 & 43.33 & 49.93 & 48.80 & 43.24 & 49.79 \\
\hline & Nitrogen & 3.6 & 0.41 & 0.99 & 0.71 & 3.76 & 1.59 \\
\hline & Sulphur & - & 0.48 & & 0.07 & 0.35 & 0.19 \\
\hline \multicolumn{2}{|c|}{ HHV (MJ/kg) } & 18.04 & 16.14 & 19.35 & 17.02 & 17.52 & 19.0 \\
\hline \multicolumn{2}{|c|}{$\begin{array}{l}\text { Moisture content after } \\
\text { drying (wt. \%) }\end{array}$} & 4 & $5-11$ & 11/11.3\# & 5.18 & 9.97 & - \\
\hline \multicolumn{2}{|c|}{ Reference } & $\begin{array}{l}\text { (SA et al., } \\
2015)\end{array}$ & $\begin{array}{l}\text { (Samiran et } \\
\text { al., 2016) }\end{array}$ & $\begin{array}{l}\text { (Erlich \& } \\
\text { Fransson, } \\
\text { 2011) }\end{array}$ & $\begin{array}{c}\text { (Mohamme } \\
\text { d et al., } \\
\text { 2011) }\end{array}$ & $\begin{array}{l}\text { (Thangavelu } \\
\text { et al., 2015) }\end{array}$ & $\begin{array}{l}\text { (Chiew et } \\
\text { al., 2011) }\end{array}$ \\
\hline
\end{tabular}

\# Values correspond to the EFB pellets of the diameter of 6 and $8 \mathrm{~mm}$, respectively. 
Table 4. A comparison of the conditions and results of the gasification of oil palm biomass.

\begin{tabular}{|c|c|c|c|c|c|c|c|c|c|c|}
\hline \multicolumn{2}{|c|}{ Oil palm biomass } & OPF & OPF & $\mathrm{OPF}$ & PKS & OPF & OPF & $\mathrm{EFB}^{\#}$ & $\mathrm{EFB}^{*}$ & EFB \\
\hline \multicolumn{2}{|c|}{$\begin{array}{c}\text { Gasifier power } \\
(\mathrm{kW})\end{array}$} & 250 & 250 & 250 & - & 50 & 50 & - & - & 106 \\
\hline \multicolumn{2}{|c|}{ Gasifying agent } & Air & Air & Air & - & Air & Air & Air & Air & Air \\
\hline \multicolumn{2}{|c|}{ Temperature $\left({ }^{\circ} \mathrm{C}\right)$} & - & - & $\begin{array}{l}700- \\
900\end{array}$ & 700 & - & - & - & - & 900 \\
\hline \multirow{5}{*}{$\begin{array}{c}\text { Gas } \\
\text { compositi } \\
\text { on } \\
\text { (vol.\%) }\end{array}$} & $\mathrm{CO}$ & 22.49 & 24.98 & 17.54 & 14 & $\begin{array}{l}18.07- \\
28.89\end{array}$ & 22.78 & 17 & 17.40 & - \\
\hline & $\mathrm{CH}_{4}$ & 1.98 & 2.49 & 1.15 & 5 & $\begin{array}{c}0.91- \\
1.76\end{array}$ & 2.02 & 1.90 & 1.50 & - \\
\hline & $\mathrm{H}_{2}$ & 9.67 & 13.58 & 9.13 & 9 & $\begin{array}{l}8.47- \\
12.59\end{array}$ & 8.47 & 13.50 & 12.90 & - \\
\hline & $\mathrm{CO}_{2}$ & - & - & 12.91 & 15 & $\begin{array}{l}7.58- \\
15.43\end{array}$ & 11.81 & 14.50 & 13.70 & - \\
\hline & $\mathrm{N}_{2}$ & - & - & 59.28 & - & $\begin{array}{l}51.40- \\
55.81\end{array}$ & - & 53.3 & 55.0 & - \\
\hline \multicolumn{2}{|c|}{$\begin{array}{c}\text { Syngas LHV } \\
\left(\mathrm{MJ} / \mathrm{Nm}^{3}\right)\end{array}$} & 4.88 & 5.9 & 3.75 & 4.84 & 4.95 & $4.66^{\text {II }}$ & 4.3 & 4.1 & 4.7 \\
\hline \multicolumn{2}{|c|}{$\begin{array}{l}\text { Gas yield } \\
\left(\mathrm{Nm}^{3} / \mathrm{kg}\right)\end{array}$} & 1.95 & 1.8 & 2.51 & - & - & 1.91 & $1.8-2.1$ & $2.1-2.5$ & - \\
\hline \multicolumn{2}{|c|}{$\begin{array}{c}\text { conversion } \\
\text { efficiency }(\%)\end{array}$} & 83.8 & 87.3 & 91.18 & - & 93.94 & 74.4 & - & - & - \\
\hline \multicolumn{2}{|c|}{$\begin{array}{c}\text { Cold gas } \\
\text { efficiency }(\%)\end{array}$} & 56.1 & 62.5 & 60.37 & 51 & - & 51.5 & - & - & 64 \\
\hline \multicolumn{2}{|c|}{ Biochar yield (\%) } & 9.3 & 8.4 & 9.4 & 29.13 & 5.2 & - & - & - & - \\
\hline \multicolumn{2}{|c|}{ Reference } & $\begin{array}{c}\text { Atnaw } \\
\text { et al. } \\
\text { (2014a) } \\
; \\
\text { Guangu } \\
\text { l et al. } \\
\text { (2013); } \\
\text { Guangu } \\
\text { l et al. } \\
\text { (2012) }\end{array}$ & $\begin{array}{c}\text { Atnaw } \\
\text { et al. } \\
\text { (2014a) } \\
\text {; } \\
\text { Guangu } \\
\text { l et al. } \\
\text { (2013); } \\
\text { Guangu } \\
\text { l et al. } \\
\text { (2012) }\end{array}$ & $\begin{array}{c}\text { Atnaw } \\
\text { et al. } \\
(2014 a)\end{array}$ & $\begin{array}{c}\text { Ariffin } \\
\text { et al. } \\
\text { (2016b) }\end{array}$ & $\begin{array}{c}\text { Atnaw } \\
\text { et al. } \\
(2014 b)\end{array}$ & $\begin{array}{c}\text { Guangu } \\
\text { l et al. } \\
(2012)\end{array}$ & $\begin{array}{c}\text { Erlich } \\
\& \\
\text { Fransso } \\
\text { n } \\
(2011)\end{array}$ & $\begin{array}{c}\text { Erlich } \\
\& \\
\text { Fransso } \\
\mathrm{n} \\
(2011)\end{array}$ & $\begin{array}{c}\text { Ariffin } \\
\text { et al. } \\
\text { (2016a) }\end{array}$ \\
\hline
\end{tabular}

II The number is with respect to HHV.

\# denotes $6 \mathrm{~mm}$ pellet.

* denotes $8 \mathrm{~mm}$ pellet. 
Table 5. LCI.

\begin{tabular}{|c|c|c|}
\hline Item & Value & Source \\
\hline \multicolumn{3}{|l|}{ Diesel-electric generator } \\
\hline $\begin{array}{l}\text { Diesel required for } 1 \text { MJ } \\
\text { electricity }\end{array}$ & $0.0667 \mathrm{~kg}$ & Ecoinvent 3.3 \\
\hline $\begin{array}{l}\text { GHG emissions for } 1 \mathrm{MJ} \\
\text { electricity }\end{array}$ & $0.25 \mathrm{~kg} \mathrm{CO}_{2 \text {-eq }}$ & Ecoinvent 3.3 \\
\hline \multicolumn{3}{|l|}{ OPT } \\
\hline Fertilizing value of 1 ton OPT & $27 \mathrm{~kg} \mathrm{CO}_{2-\mathrm{eq}}$ & $\begin{array}{c}\text { Calculated based on OPT element } \\
\text { composition }\end{array}$ \\
\hline \multicolumn{3}{|l|}{ Gasification } \\
\hline Kerosene usage & $10 \mathrm{~L} /$ year/gasifier & Assumed \\
\hline Fly ash production & $8.941 \mathrm{~g} / \mathrm{kg} \mathrm{DM}$ & Ecoinvent 3.3 data for softwood \\
\hline Biochar production & $123 \mathrm{~g} / \mathrm{kg} \mathrm{DM}$ & \\
\hline Carbon content in the biochar & $80 \%$ & \\
\hline Recalcitrant carbon in biochar & $80 \%$ & Galinato et al. (2011) \\
\hline Syngas production rate & $2 \mathrm{Nm}^{3}$ syngas/kg solar dried material & \\
\hline Syngas composition & $20 \% \mathrm{CO}, 2 \% \mathrm{CH}_{4}, 11 \% \mathrm{H}_{2}$ & Average value from literature \\
\hline $\begin{array}{l}\text { GHG emissions from syngas } \\
\text { engine }\end{array}$ & $0.05 \mathrm{~g} / \mathrm{Nm}^{3}$ syngas & $\begin{array}{l}\text { Calculated based on methane } \\
\text { concentration in syngas }^{\mathrm{a}}\end{array}$ \\
\hline \multicolumn{3}{|l|}{ Combustion } \\
\hline Combustion ash production rate & $7 \%$ of the DM of feedstock & Doka (2014) \\
\hline $\mathrm{K} \%$ in mill solid residue & $1.89 \%$ & Sung (2016) \\
\hline $\begin{array}{l}\text { K transfer coefficient from } \\
\text { feedstock to combustion ash }\end{array}$ & $41.2 \%$ & $\begin{array}{c}\text { Ecoinvent } 3.3 \text { data for incineration } \\
\text { plant }\end{array}$ \\
\hline Wastewater $\left(\mathrm{m}^{3}\right)$, average & $1.49 \times 10^{-5} \mathrm{~m}^{3} / 1 \mathrm{~kg}$ dry feedstock & \multirow{12}{*}{$\begin{array}{l}\text { Ecoinvent } 3.3 \text { dataset for wood chips } \\
\text { burning in the boiler with a capacity of } \\
6667 \mathrm{~kW} \text { is utilized to describe the } \\
\text { emissions of burning mill solid residue. }\end{array}$} \\
\hline Waste mineral oil & $6.20 \times 10^{-5} \mathrm{~kg} / 1 \mathrm{~kg}$ dry feedstock & \\
\hline Municipal solid waste & $6.20 \times 10^{-5} \mathrm{~kg} / 1 \mathrm{~kg}$ dry feedstock & \\
\hline Chlorine, gaseous & $6.20 \times 10^{-6} \mathrm{~kg} / 1 \mathrm{~kg}$ dry feedstock & \\
\hline Ammonia, liquid & $1.55 \times 10^{-7} \mathrm{~kg} / 1 \mathrm{~kg}$ dry feedstock & \\
\hline Water $(\mathrm{kg})$, decarbonised & $1.49 \times 10^{-2} \mathrm{~kg} / 1 \mathrm{~kg}$ dry feedstock & \\
\hline Sodium chloride, powder & $7.75 \times 10^{-5} \mathrm{~kg} / 1 \mathrm{~kg}$ dry feedstock & \\
\hline Lubricating oil & $6.20 \times 10^{-5} \mathrm{~kg} / 1 \mathrm{~kg}$ dry feedstock & \\
\hline Chemical, organic & $1.11 \times 10^{-4} \mathrm{~kg} / 1 \mathrm{~kg}$ dry feedstock & \\
\hline Dinitrogen monoxide & $4.35 \times 10^{-5} \mathrm{~kg} / 1 \mathrm{~kg}$ dry feedstock & \\
\hline Methane & $0.95 \mathrm{~kg} / 1 \mathrm{~kg}$ dry feedstock & \\
\hline Transportation & & \\
\hline Lorry 16-32 metric ton, EURO3 & $0.168 \mathrm{~kg} / \mathrm{tkm}$ & Ecoinvent 3.3 \\
\hline
\end{tabular}


${ }^{a}$ For the modelling of syngas combustion, it is assumed that $\mathrm{CO}$ is converted completely to $\mathrm{CO}_{2}$, and that $\mathrm{CO}_{2}$ does not react in the combustion process and is emitted as it is. $\mathrm{CH}_{4}$ is considered as 'natural gas' and modelled according to the emissions of the process 'natural gas burned in industrial boiler $>100 \mathrm{~kW}$ (emissions only)'. $\mathrm{H}_{2}$ is converted to water. 
Table 6. List of system parameters for LCA and CBA.

\begin{tabular}{|c|c|c|c|}
\hline Item & Unit & Value & Reference \\
\hline System life time & Year & 25 & Balamurugan et al. (2009) \\
\hline Gasification system & USD $/ \mathrm{kW}$ & $1500 \&$ & $\begin{array}{c}\text { Abe et al. (2007); Suramaythangkoor \& } \\
\text { Gheewala (2010) }\end{array}$ \\
\hline O\&M (gasification system) & $\%$ & $16.8^{*}$ & You et al. (2016) \\
\hline$C G E$ & $\%$ & 58 & Table 2 \\
\hline$E F$ & $\%$ & 42 & François et al. (2013) \\
\hline Combustion system & USD/kW & 1200 & Malek et al. (2017) \\
\hline O\&M (Combustion system) & $\%$ & $4^{*}$ & Malek et al. (2017) \\
\hline Overall EF (Combustion system) & $\%$ & 15 & González et al. (2015) \\
\hline Kerosene & USD/L & 0.9 & Dufo-López et al. (2011) \\
\hline Kerosene usage & L//gasifier/year & 10 & This work \\
\hline Diesel generator & $\mathrm{USD} / \mathrm{kW}$ & 250 & Thangavelu et al. (2015) \\
\hline O\&M (Diesel generator) & USD/kW/year & 18 & Thangavelu et al. (2015) \\
\hline Overall $E F$ (Diesel generator) & $\%$ & 27 & Thangavelu et al. (2015) \\
\hline Diesel & USD/liter & 0.32 & Blum et al. (2013) \\
\hline Heating rate of diesel & $\mathrm{MJ} / \mathrm{L}$ & 35 & Rodríguez-Fernández et al. (2017) \\
\hline Mini-grid cost & USD/meter & 20 & Adaramola et al. (2014) \\
\hline Transmission length & meter & 25 & Adaramola et al. (2014) \\
\hline Biochar & USD/ton & $0,500,2650$ & $\begin{array}{l}\text { Choppala et al. (2012); Liu et al. } \\
\text { (2013); Meyer et al. (2011) Ahmed et } \\
\text { al. (2016) }\end{array}$ \\
\hline Biochar yield & $\%$ & 12.3 & Table 2 \\
\hline Electricity tariff & USD/kWh & $0.1-0.3$ & This work \\
\hline
\end{tabular}

\&: The cost includes all components of the system (i.e. gasifier, syngas cleaning, and engine).

*: The value denotes the ratio between the O\&M cost and capital cost. 
Table 7. Cost and benefit components and biochar production for the proposed scenarios.

\begin{tabular}{|c|c|c|c|c|c|c|c|c|c|c|c|c|c|c|}
\hline \multirow[b]{2}{*}{$\begin{array}{l}\text { Scenari } \\
\text { os }\end{array}$} & \multicolumn{5}{|c|}{ Conditions } & \multicolumn{6}{|c|}{ Cost and benefit components } & \multirow{2}{*}{$\begin{array}{c}\text { Biochar } \\
\text { product } \\
\text { ion per } \\
\text { system } \\
\text { (ton/ye } \\
\text { ar) } \\
\end{array}$} & \multirow[b]{2}{*}{$\begin{array}{l}\text { NPV } \\
\text { (USD) }\end{array}$} & \multirow[b]{2}{*}{$\begin{array}{c}\text { LCOE } \\
\text { (USD/k } \\
\text { Wh) }\end{array}$} \\
\hline & $\begin{array}{c}\mathrm{ET} \\
(\mathrm{USD} / \mathrm{kW} \\
\mathrm{h})\end{array}$ & $\begin{array}{c}\text { Deman } \\
\mathrm{d} \\
(\mathrm{kWh})\end{array}$ & $\begin{array}{l}\text { Capacit } \\
\text { y factor }\end{array}$ & $\begin{array}{c}\text { Biochar } \\
\text { price } \\
\text { (USD/ton) }\end{array}$ & $\begin{array}{c}\text { Number } \\
\text { of } \\
\text { household } \\
\text { s }\end{array}$ & $\begin{array}{c}\text { System } \\
\text { cost } \\
\text { (USD) }\end{array}$ & $\begin{array}{c}\text { O\&M } \\
\text { cost } \\
\text { (USD) }\end{array}$ & $\begin{array}{l}\text { Mini- } \\
\text { grid cost } \\
\text { (USD) }\end{array}$ & $\begin{array}{c}\text { Kerosene } \\
\text { cost } \\
\text { (USD) }\end{array}$ & $\begin{array}{c}\text { Electricit } \\
\text { y income } \\
\text { (USD) }\end{array}$ & $\begin{array}{c}\text { Biochar } \\
\text { income } \\
\text { (USD) }\end{array}$ & & & \\
\hline V1 & 0.11 & 0.4 & $2.8 \%$ & 500 & 300 & $3.2 \times 10^{5}$ & $1.4 \times 10^{6}$ & $1.5 \times 10^{5}$ & 225 & $1.2 \times 10^{5}$ & $7.0 \times 10^{4}$ & 5.6 & $9.0 \times 10^{5}$ & 2.16 \\
\hline V1 & 0.11 & 0.4 & $100 \%$ & 500 & 300 & $3.2 \times 10^{5}$ & $1.4 \times 10^{6}$ & $1.5 \times 10^{5}$ & 225 & $1.2 \times 10^{5}$ & $2.6 \times 10^{6}$ & 208 & $1.3 \times 10^{4}$ & 0.06 \\
\hline V2 & 0.11 & 0.4 & $100 \%$ & 500 & 300 & $2.6 \times 10^{4}$ & $1.1 \times 10^{5}$ & $1.5 \times 10^{5}$ & 225 & $1.2 \times 10^{5}$ & $7.6 \times 10^{4}$ & 6.08 & $\begin{array}{c}- \\
1.5 \times 10^{5}\end{array}$ & 0.46 \\
\hline M1 & 0.11 & 11000 & $7.4 \%$ & 500 & - & $9.4 \times 10^{6}$ & $4.0 \times 10^{7}$ & 492.3 & 225 & $8.0 \times 10^{6}$ & $4.5 \times 10^{6}$ & 360 & $\begin{array}{c}- \\
2.0 \times 10^{7}\end{array}$ & 0.83 \\
\hline M1 & 0.11 & 11000 & $100 \%$ & 500 & - & $9.4 \times 10^{6}$ & $4.0 \times 10^{7}$ & 492.3 & 225 & $8.0 \times 10^{6}$ & $6.1 \times 10^{7}$ & 4880 & $7.8 \times 10^{5}$ & 0.06 \\
\hline M2 & 0.11 & 11000 & $100 \%$ & 500 & - & $1.6 \times 10^{6}$ & $6.6 \times 10^{6}$ & 492.3 & 225 & $8.0 \times 10^{6}$ & $4.9 \times 10^{6}$ & 392 & $6.9 \times 10^{5}$ & 0.15 \\
\hline
\end{tabular}




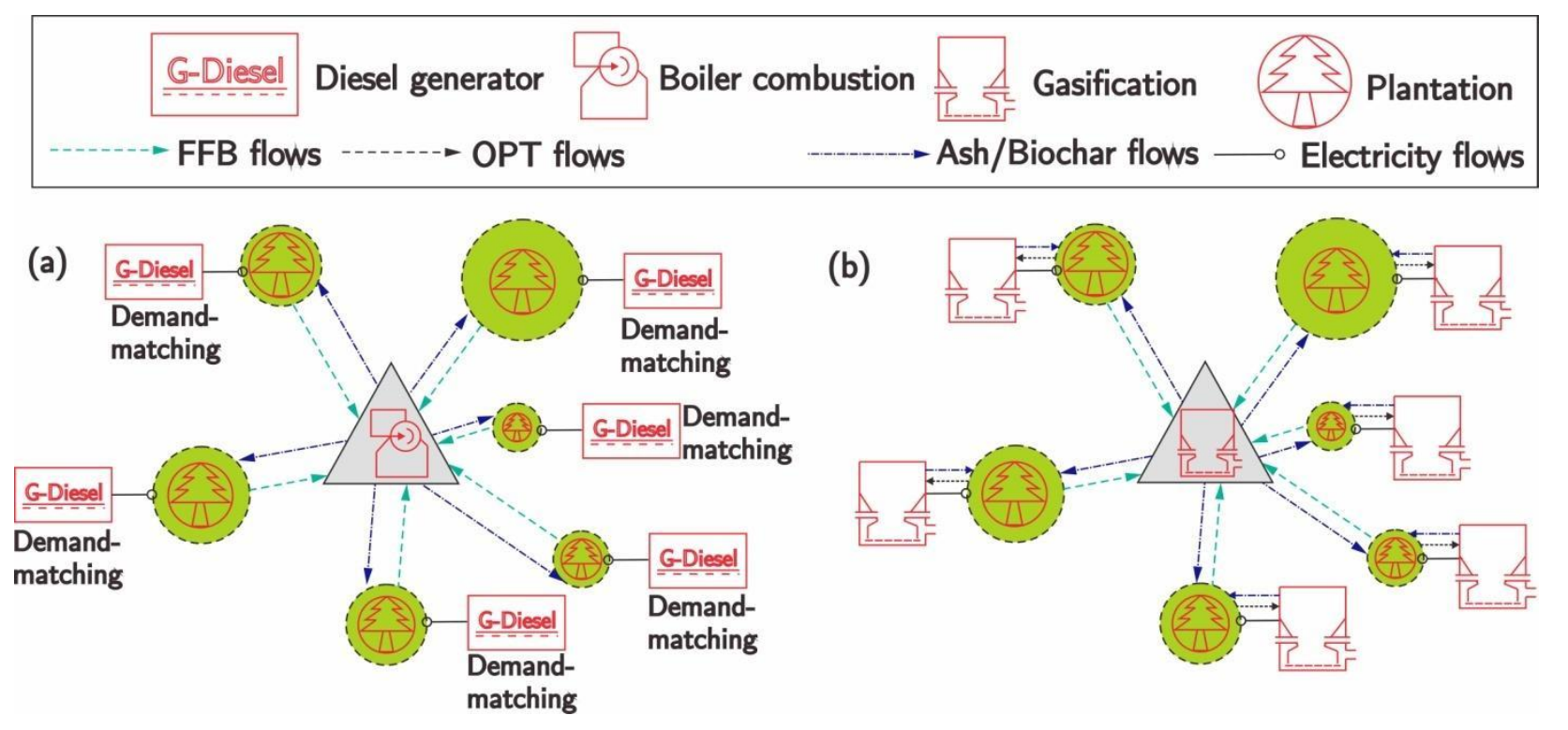

Figure 1. A schematic of the (a) reference and (b) proposed scenarios. Green circles denote villages and the gray triangle denotes the palm oil mill. In the reference scenario, the villages are powered by diesel generators while the mill is powered by a combustion-based system whose capacity is determined by either the amount of biomass available (Table 1) or the daily mill electricity demand. In the proposed scenario, the villages are powered by gasification systems whose capacity is determined by either the amount of biomass available (Table 1) or the daily village electricity demand, and the mill is powered by a gasification system whose capacity is determined by either the amount of biomass available (Table 1) or the daily mill electricity demand. 


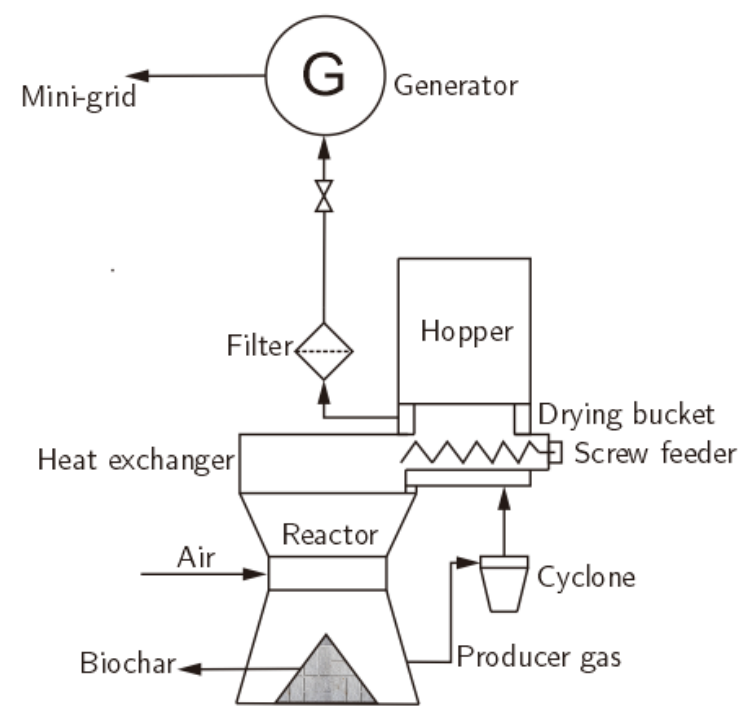

Figure 2. A schematic diagram of a generic downdraft fixed-bed gasification system. 

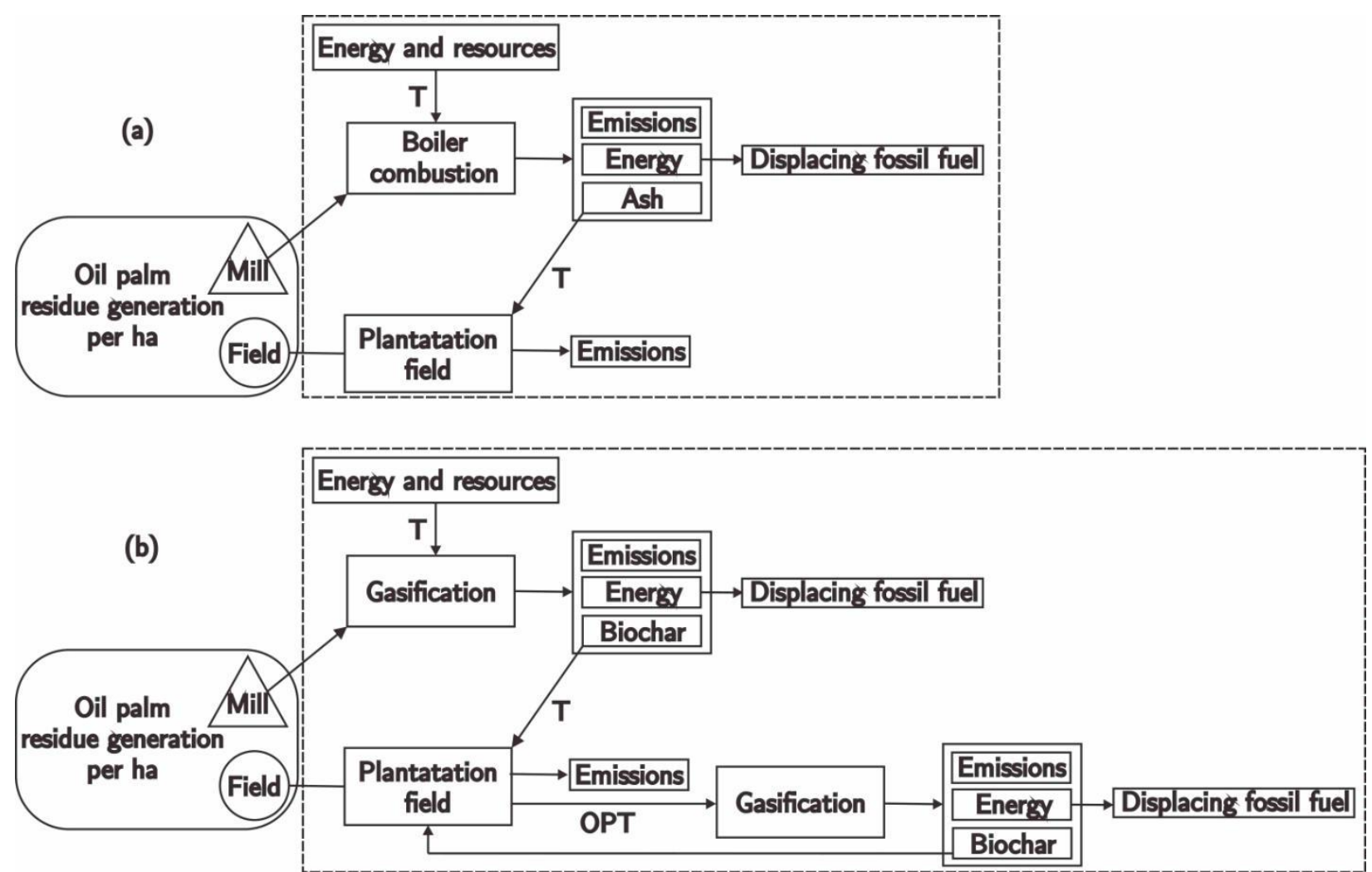

Figure 3. The LCA boundary (dash lines) for the reference scenarios (a) and new scenarios (b). T denotes transportation. 


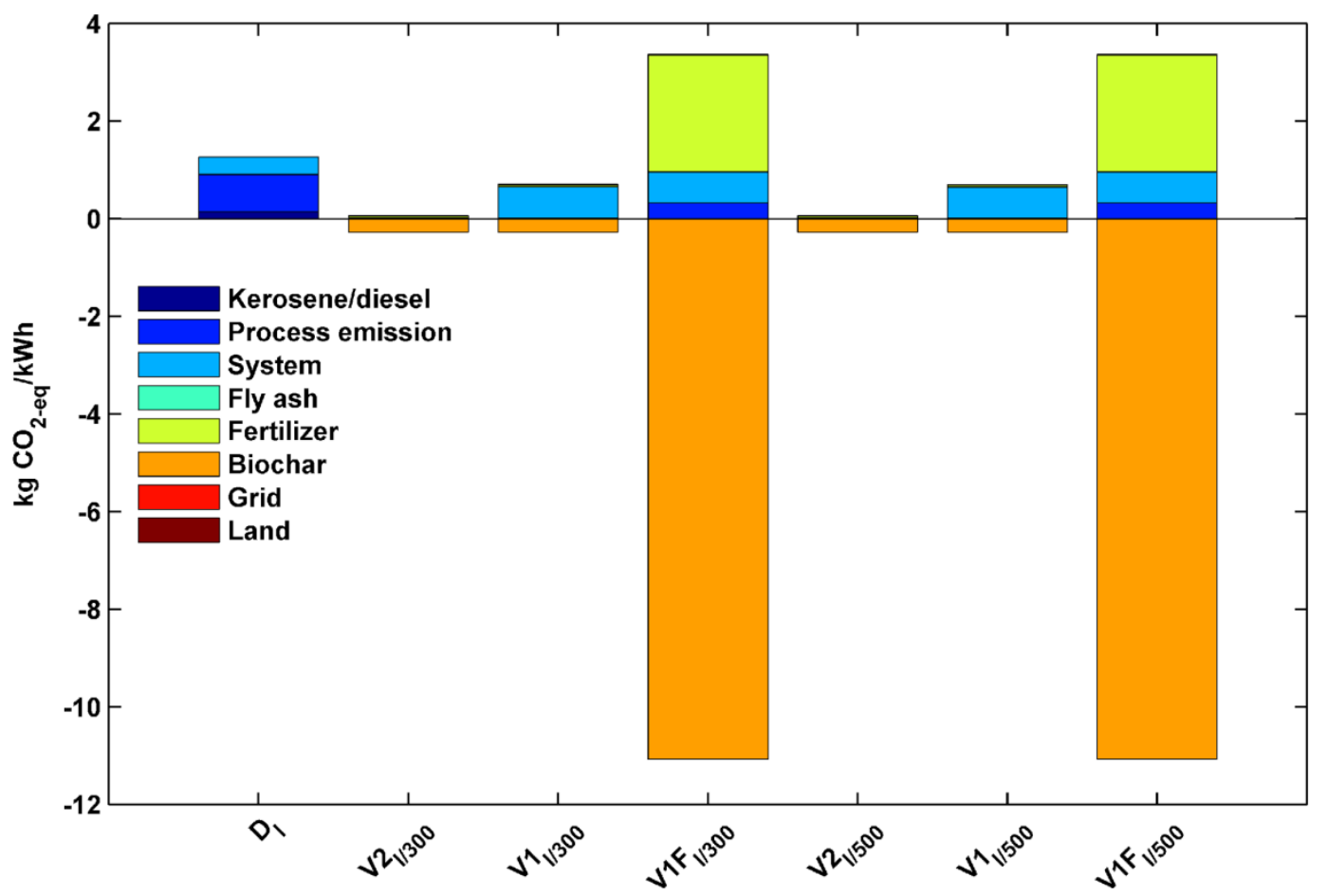

Figure 4. The global warming (GW) impacts of the reference scenarios and proposed alternatives for a village. $D_{1}$ : the diesel generator (reference) scenario with the current household electricity demand $(0.4 \mathrm{kWh}) ; \mathrm{V} 2_{1 / 300}$ : V2 (0.4 kWh and 300 households); V1 $1_{1 / 300}$ :

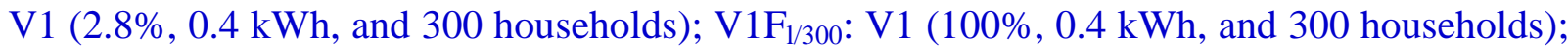
$\mathrm{V} 2_{1 / 500}: \mathrm{V} 2(0.4 \mathrm{kWh}$ and 500 households); V1 $1 / 500: \mathrm{V} 1$ (2.8\%, $0.4 \mathrm{kWh}$, and 500 households);

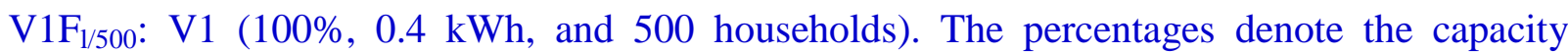
factors. 


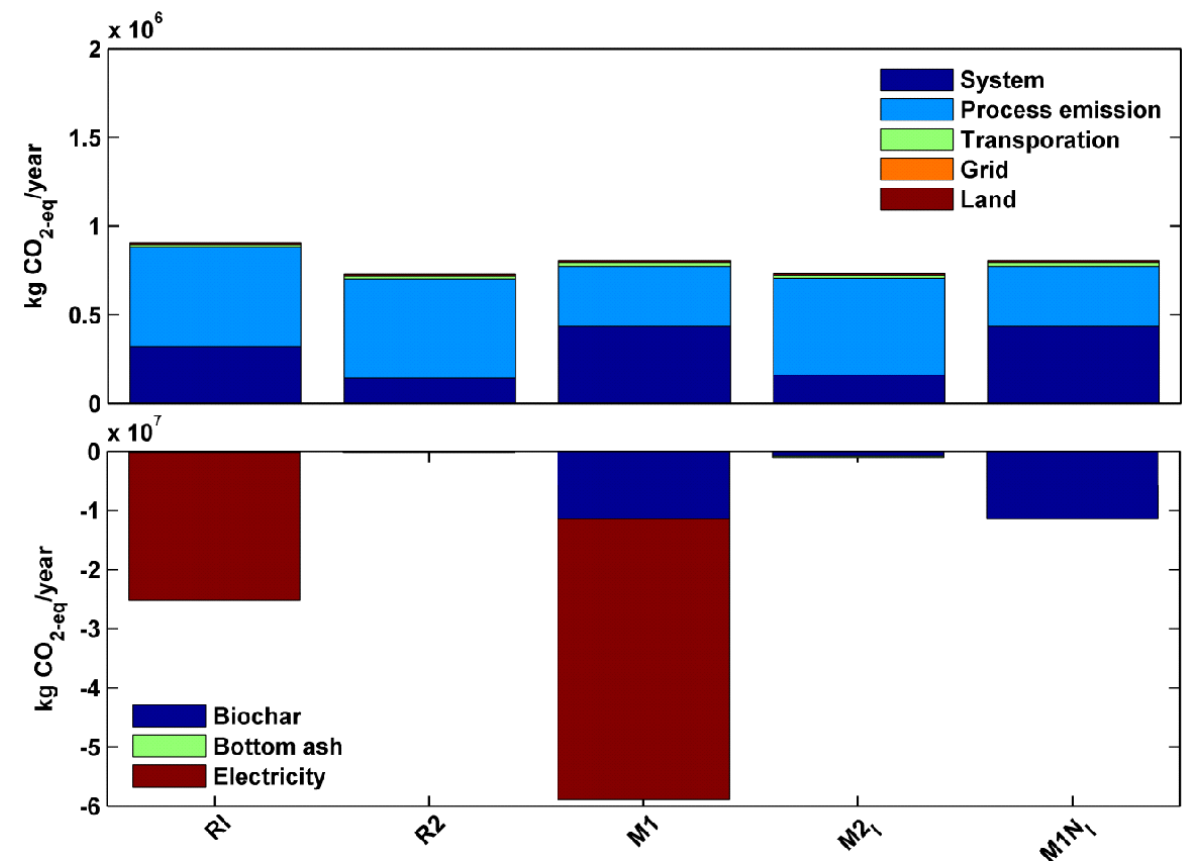

Figure 5. The GW impacts of the reference scenarios and proposed alternatives for a mill. R1: the electricity could be fed into the national grid. R2: the electricity just satisfies to the mill. M1: $100 \%$ capacity factor and electricity fed into the national grid; M21: M2 under the mill electricity demand of $11000 \mathrm{kWh} ; \mathrm{M}_{\mathrm{N}}$ : M1 with $100 \%$ capacity factor but without the national grid connection. Note that the scales of y-axis between the upper and lower sub-plots are different. 

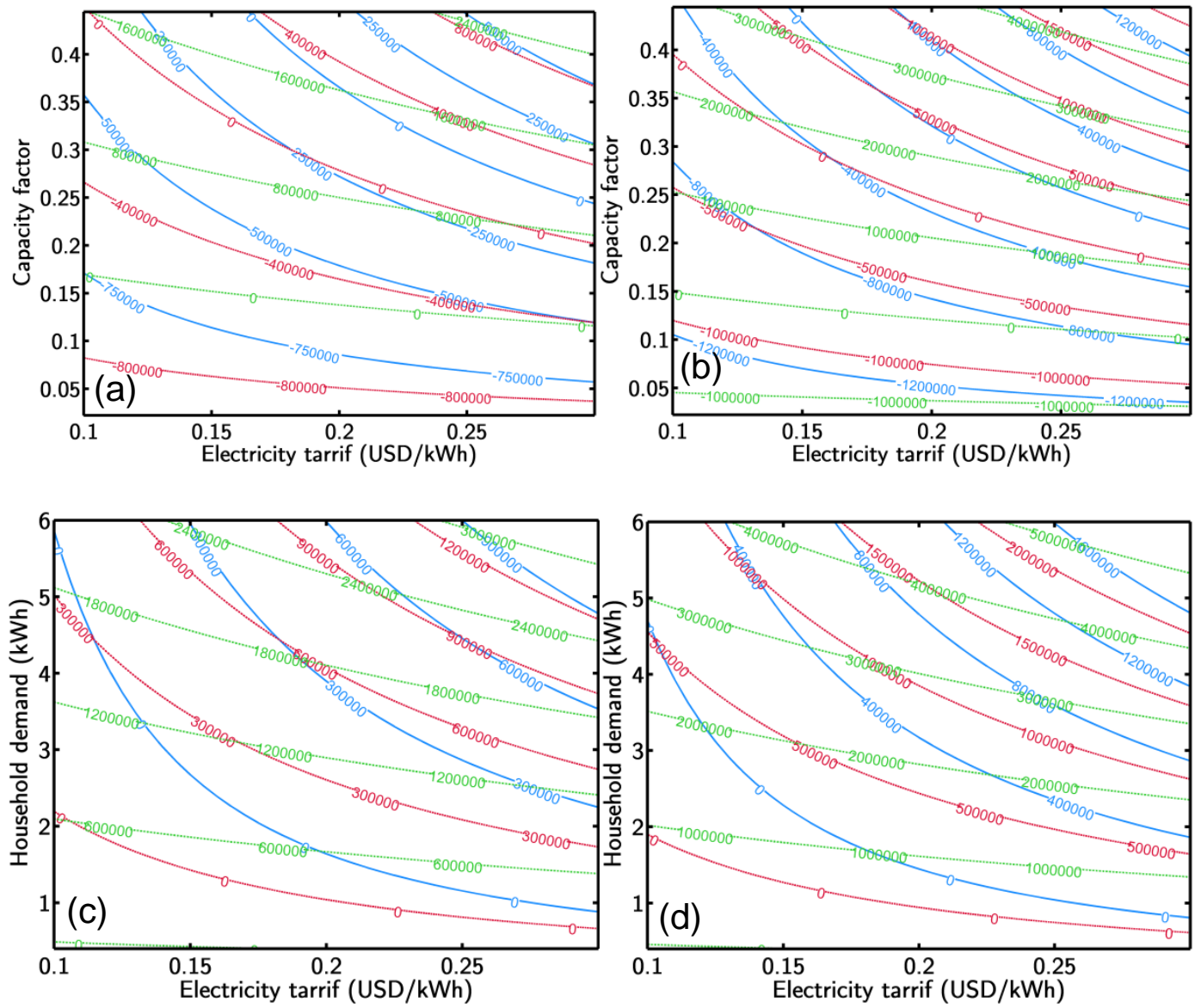

Figure 6. The contours of mean NPV with respect to the capacity factor and ET for V1 ((a) and (b)), and the household demand and ET for V2 ((c) and (d)). (a) and (c) correspond to 300 households. (b) and (d) correspond to 500 households. The blue, red, and green lines denote the biochar prices of 0,500 , and $2650 \mathrm{USD} /$ ton, respectively. 

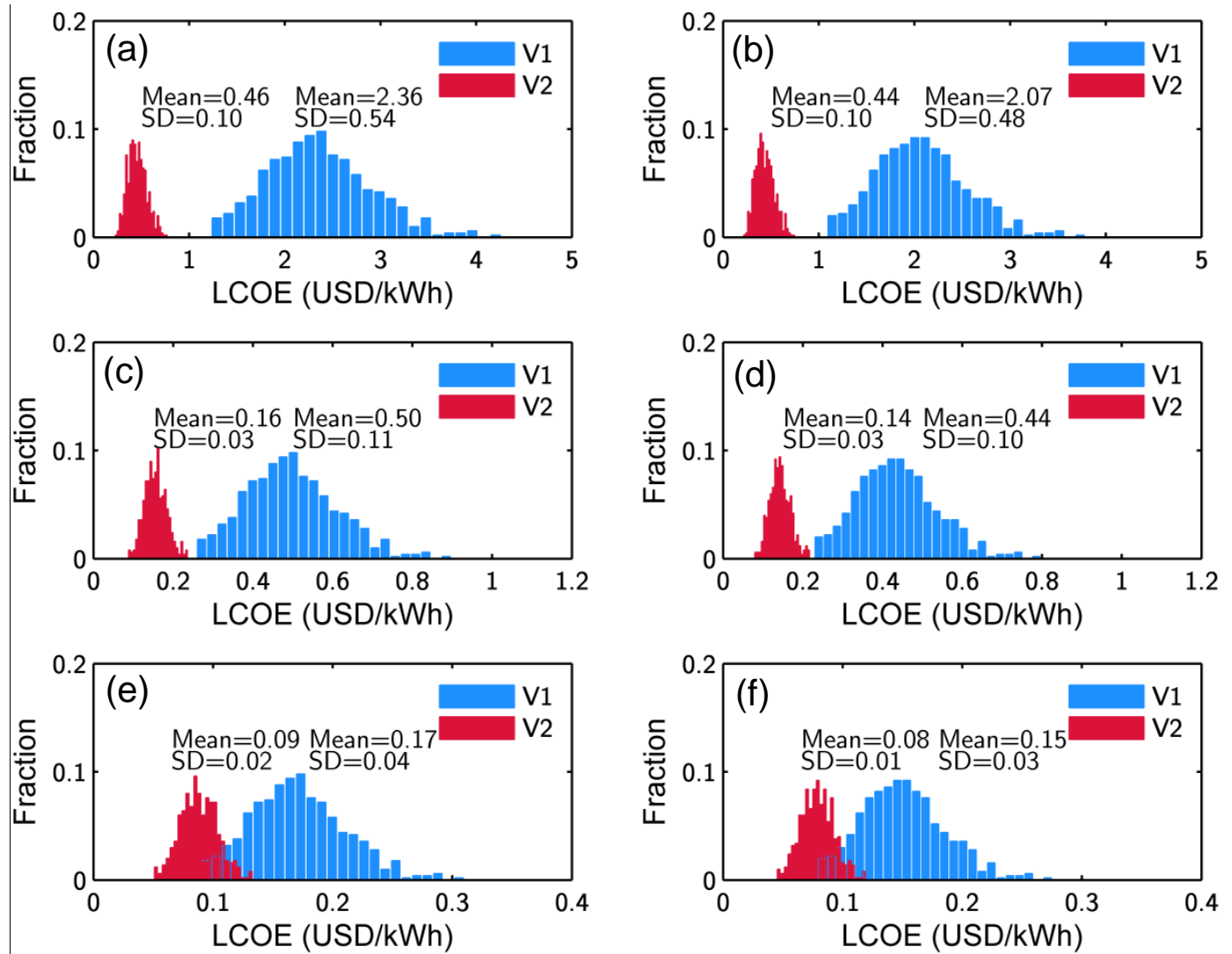

Figure 7. The distributions of LCOE for V1 and V2 for the cases of 300 ((a), (c), and (e)) and 500 ((b), (d), and (f)) households. (a) and (b), (c) and (d), and (e) and (f) correspond to the household demands (capacity factor) of 0.4 (2.8\%), $1.9(13.1 \%)$, and $5.5 \mathrm{kWh}(38.0 \%)$, respectively for V2 (for V1). 

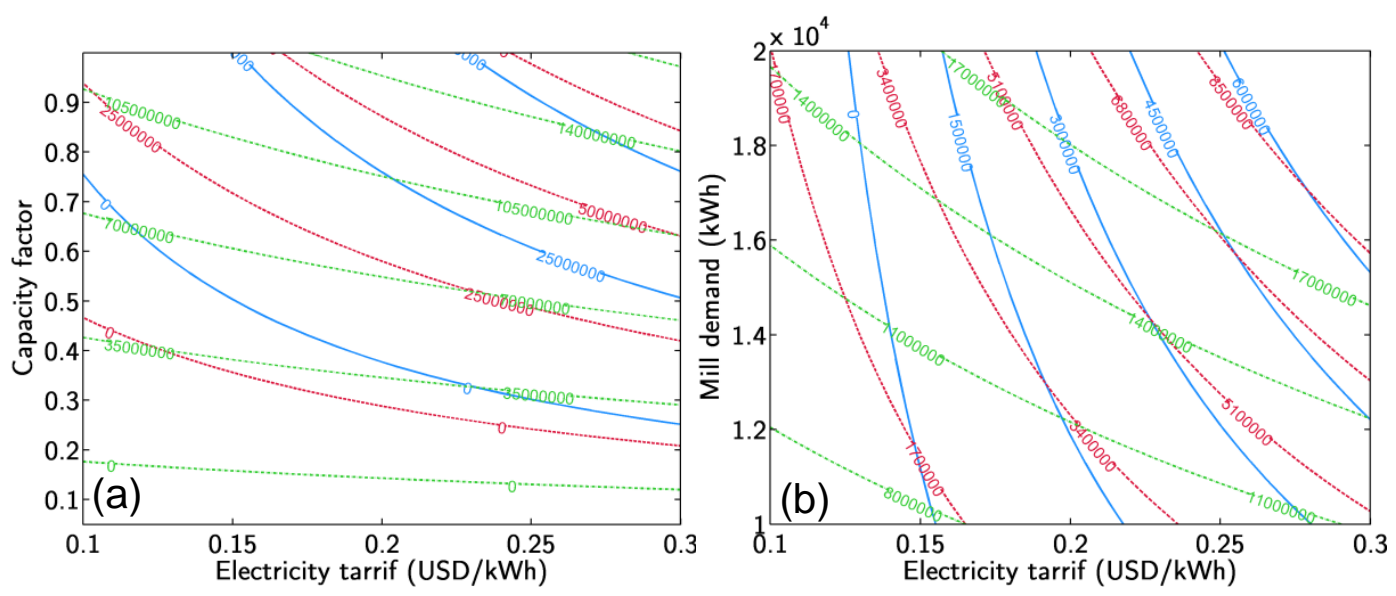

Figure 8 . The contours of mean NPV with respect to the capacity factor and ET for (a) M1, and with respect to the mill demand and ET for (b) M2. The blue, red, and green lines denote the biochar price cases of 0,500 , and 2650 USD/ton, respectively. 

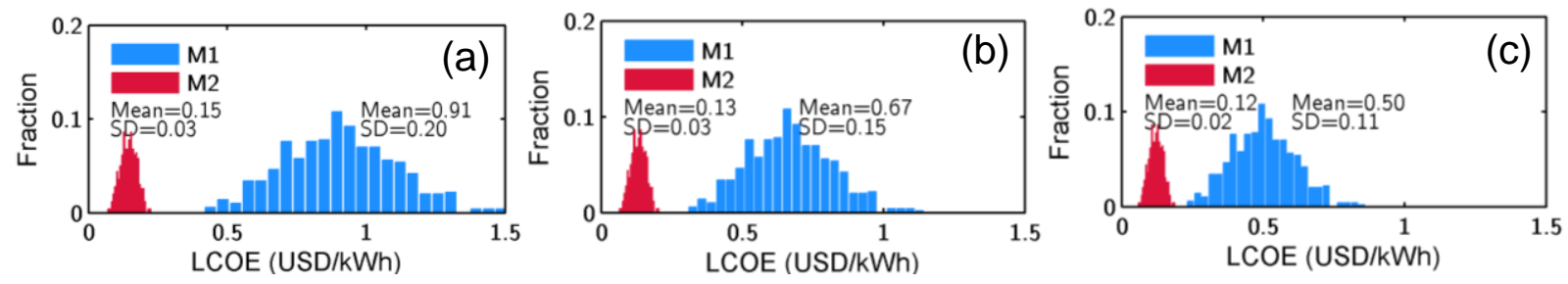

Figure 9. The distributions of LCOE for M1 and M2. For M1, (a), (b), and (c) correspond to the capacity factors of $7.4 \%$ (lower), $10.1 \%$ (medium), and $13.4 \%$ (higher), respectively. For M2, (a), (b), and (c) correspond to the daily mill demand of 11000, 15000, and $20000 \mathrm{kWh}$, respectively. 

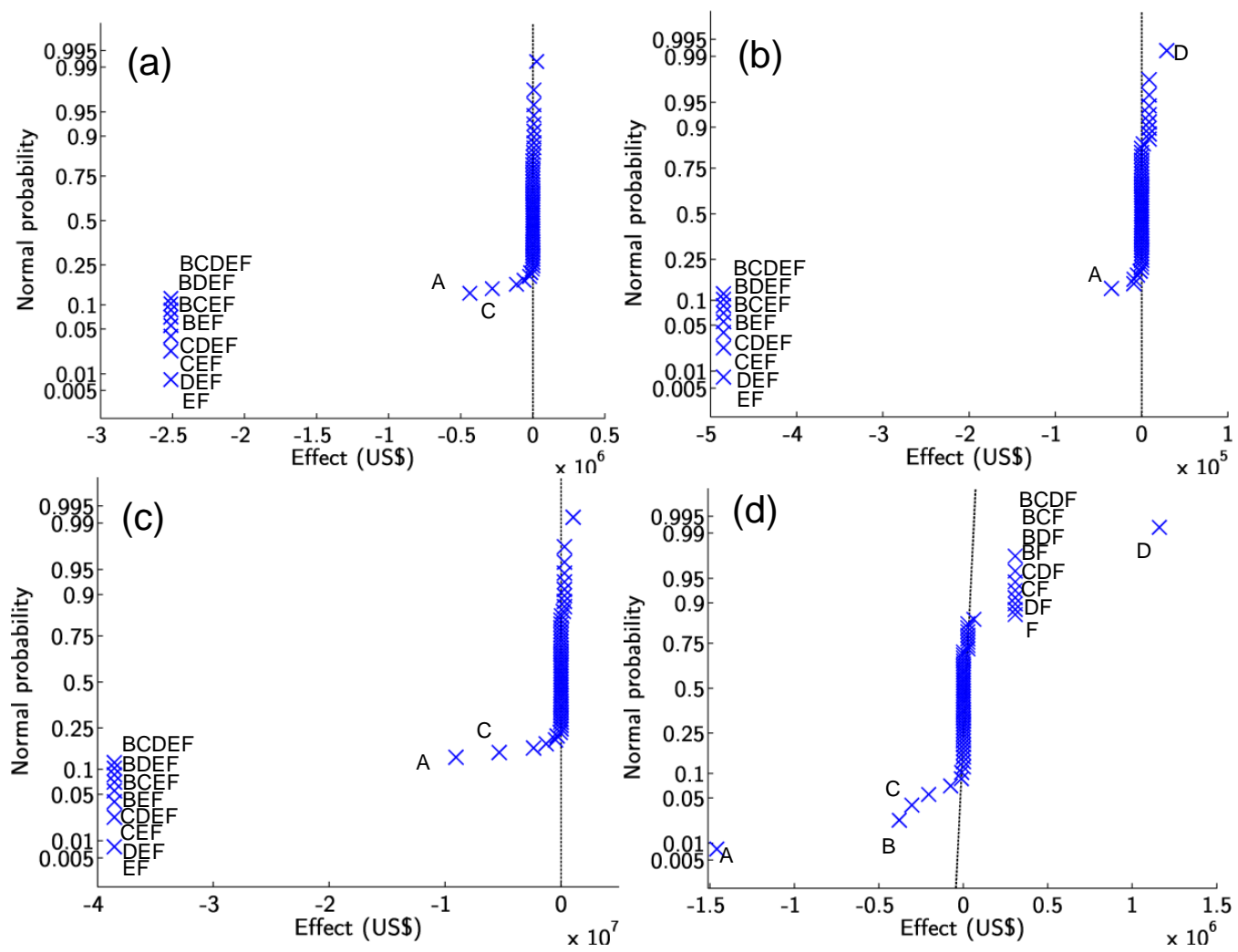

Figure 10. Sensitivity analysis shown in normal probability plots for (a) V1, (b) V2, (c) M1, and (d) M2. 
Supplementary Interactive Plot Data (CSV)
Click here to download Supplementary Inte

Click here to download Supplementary Interactive Plot Data (CSV): Supplementary Material.docx 